\title{
Phenotype and Differentiation Potential of Stromal Populations Obtained from Various Zones of Human Umbilical Cord: An Overview
}

\author{
Maria Teresa Conconi ${ }^{*} \S$, Rosa Di Liddo ${ }^{\S}$, Mara Tommasini, Chiara Calore and \\ Pier Paolo Parnigotto
}

Department of Pharmaceutical Sciences, University of Padua, via Marzolo 5, 35131 Padova, Italy

\begin{abstract}
Fibroblast-like cells with properties similar to mesenchymal stromal cells (MSCs) are present in human umbilical cord (hUC). In accordance with the international minimal criteria for defining multipotent mesenchymal stromal cells, hUC cells are designed MSCs being plastic adherent, positive to specific non hematopoietic lineage biomarkers, able to be both in vitro long term cultured and differentiated into osteoblasts, chondroblasts and adipocytes. In this review, a panoramic view of phenotypic characteristics of hUC cells derived from various UC parts are described. The high heterogeneity of extraction, culture and analysis procedures hinder the ability to precisely identify UC stromal cells. As a result, different phenotypic profiles are detectable not only among the cells obtained from the various parts of cord, but also inside the same UC regions, suggesting that UC-MSCs may represent an unique cell family whose components present various degree of stemness. However, in vitro and in vivo evidence indicates Wharton's jelly as the best source of MSCs, because its cells present a wide range of potential therapeutic applications.
\end{abstract}

Keywords: Umbilical cord, phenotype, cell differentiation.

\section{INTRODUCTION}

Since 1991, when McElreavey et al., [1] reported the isolation of fibroblast-like cells from the Wharton's jelly of human umbilical cord (hUC), a great deal of effort has been devoted to obtaining, characterizing and evaluating both in vitro and in vivo hUC cells in order to identify a new source of mesenchymal stromal cells (MSCs) for therapeutic use. The hUC cells have shown to share with MSCs the surface phenotype, plastic adherence, and multipotency. Indeed, under suitable stimuli, they differentiate in vitro into adipocytes, osteoblasts, chondrocytes, hepatocytes, cardiac and neural cells [2-5]. Differentiation of UC cells into germ like cells has also been achieved [6]. Other properties make these cells more attractive than other MSCs. Firstly, UC is considered as medical waste and its use is completely free from ethical concerns. Secondly, hUC cells present reduced immunogenicity: the transplantation of hUC cells into nonimmune-suppressed animals does not induce acute rejection [7]. Thirdly, hUC cells may modulate immune function because they produce several cytokines and growth factors and lack costimulatory molecules [8]. Furthermore, when compared with MSCs from bone marrow (BM), they exhibit higher frequency of colony-forming-unit fibroblasts (CFU-F) and shorter population doubling time [9].

To date, hUCs possessing MSC properties can be obtained from the UC lining, the Wharton's jelly, the subendothelial layer, the perivascular zone, or whole UC. Several extraction methods and culture media have been used

\footnotetext{
*Address correspondence to this author at the Department of Pharmaceutical Sciences, Via Marzolo, 5, 35131 Padova, Italy;

Tel: +390488275714; Fax: +390498275366;

E-mail: mariateresa.conconi@unipd.it

${ }^{\S}$ The Authors contributed equally to the work
}

according to the cell source. According to the isolation method and ex vivo culture conditions, hUC cells show a highly heterogeneous self-renewal capacity, immunophenotype, and differentiative potential suggesting that populations with different stemness grade may be distributed within all UC compartments. In the present work, a panoramic view of the phenotypic characteristics of hUC cells derived from various UC parts are described. Furthermore, despite several contradictory findings due to the high heterogeneity in the extraction and culture procedures, comparisons between hUC cells and bone marrow (BM)-MSCs have been attempted.

\section{HUMAN UMBILICAL CORD}

The hUC is embryologically derived on day 26 of gestation from extraembyronic mesoderm and/or embryonic mesoderm. At birth, it weighs approximately $40 \mathrm{~g}$, its length is about $30-65 \mathrm{~cm}$, and its mean diameter is $1.5 \mathrm{~cm}$. During pregnancy, the hUC represents a vascular link between mother and fetus, and protects the blood vessels assuring blood supply and removal of biological waste to and from fetus, respectively. Its surface is covered with a simple epithelium of amniotic derivation, which stratifies in late gestation. Transverse section reveals two umbilical arteries and a single umbilical vein surrounded by mucous connective tissue, named Wharton's jelly (Fig. 1). The umbilical arteries lack both internal and external elastic lamina and the adventitia is replaced by mucous connective tissue. The umbilical vein is characterized by a thick muscularis layer containing variously oriented smooth muscle fibers. All vessels are normally organized as left spiral turns. No capillaries and lymphatics are present. Wharton's jelly is mainly composed of ground substance, rich in sulfated proteoglycans, and several types of collagenous fibers, but 
lacking in elastic ones. Due its resistance to twisting and compression, its main role is to protect blood vessels thus allowing an efficient blood flow between fetal and maternal circulation. The most abundant glycosaminoglycan is hyaluronic acid, whereas fibers are mainly composed of collagen types I and III. The structure of hUC extracellular matrix has been reviewed by Can and Karahuseyinoglu [10]. The stromal cells of the Wharton's jelly are fibroblast-like cells which produce the extracellular matrix. Like myofibroblasts, they express vimentin, desmin, and $\alpha$-smooth muscle actin (SMA) [11]. To date, various cell populations have been identified in the defined hUC compartments: amnion-derived epithelium, subamniotic region, Wharton's jelly, perivascular stroma and vessels.

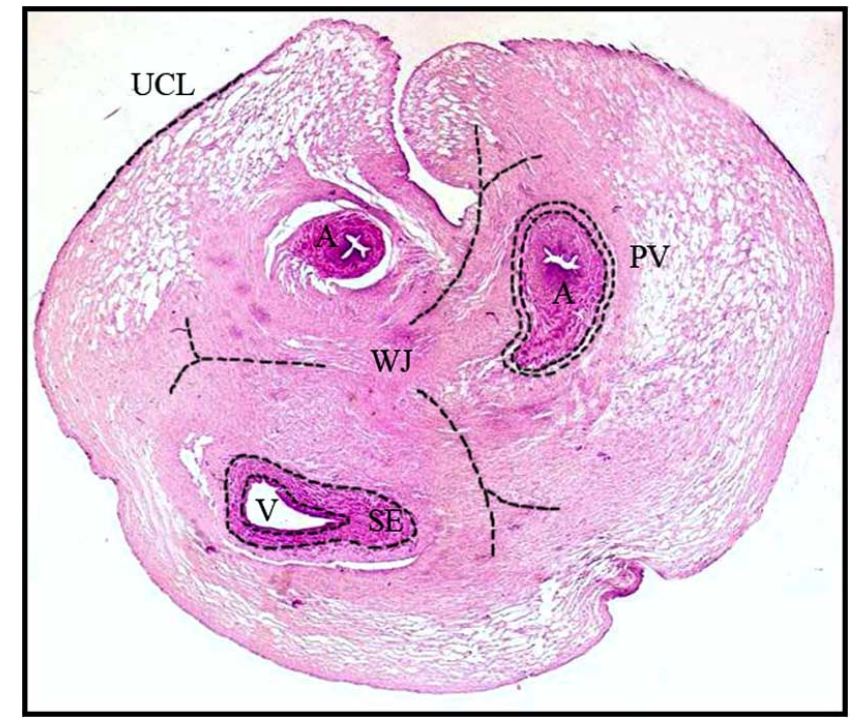

Fig. (1). Hematoxyllin-eosyn staining of hUC sections (magnification: x200). A: artery; V: vein; SE: subendothelial layer; PV: perivascular layer; WJ: Wharton's jelly; UCL: umbilical cord lining.

\section{MESENCHYMAL STROMAL CELLS OF HUMAN UMBILICAL CORD}

In the last few decades a growing number of researchers have focused on MSCs due to their potential use not only in cell therapy, but also in relation to development and regeneration. MSCs have been isolated from several tissues of both fetal and adult origin, including hUC [12]. Being quite numerous in fetal blood during the first trimester of pregnancy [13], it has been hypothesized that MSCs could leave the blood stream and localize into hUC during advancing gestation. MSCs are present in many parts of hUC from the vessels to the amnionic membrane. They all share a fibroblast-like morphology, a high proliferation rate, and multipotent differentiation properties. Nevertheless, it seems very difficult to compare MSCs obtained from the various parts of hUC with each other as the heterogeneity of cell isolation methods and used culture media is high. Indeed, different cell populations can be obtained by enzymatic procedures or explant cultures. Moreover, according to the various research groups, the panel of stemness markers used to characterize these cell populations varies a great deal. And furthermore, it has to be highlighted that the phenotypic characterization has been carried out at different culture passages and the percent variations in marker expression during culturing have been reported in only few papers. In this section, the phenotypic features of MSCs obtained from hUC compartments together with the corresponding extraction methods, the used culture conditions and the differentiation potential are summarized. Overall, all MSCs fit the defining criteria of Mesenchymal and Tissue Stem Cell Committee of the International Society for Cell Therapy [14]. They share fibroblast-like morphology and a nonhematopoietic phenotype, lacking hematopoietic markers, such as CD14, CD34, CD38, CD45, and CD133. In addition, they express human leukocyte antigen (HLA) class I but not HLA class II.

\subsection{MSCs from the Subendothelial Layer}

To retrieve the subendothelial layer cells, the cord vein is filled with collagenase and incubated at $37^{\circ} \mathrm{C}$. After washing and gently massaging the cord, cell suspension is collected and seeded. Despite this common procedure, each research group has used different types of collagenase (I or IV), enzyme concentration $(0.1,0.5$, and $1 \%)$, incubation times and culture media [15-22]. In particular, a five hour incubation period compared to shorter ones (ranging from 10 to 20 min) could assure complete digestion of the subendothelial layer leading to an enrichment of cell suspension. Nevertheless, it can not be excluded that a decrease in cell viability may occur. Then, the cells are cultured in DMEM low glucose (LG), MEM or M199 media supplemented with $10 \%$ fetal bovine serum (FBS) or fetal calf serum (FCS), but without exogenous growth factors that could induce cell differentiation. Although endothelial cells are present in primary cultures, they do not spread, migrate or proliferate using the above mentioned media. As a result, the cultures contain only MSCs and are free of contaminating endothelium. However, the absence of endothelial markers, such as CD31, von Willebrand factor (vWf) and kinase insert domain receptor (KDR), has been verified in only half the papers on MSCs from the subendothelial zone [17-19, 22]. As reported in Table 1, in addition to CD105, CD73, and CD90, MSCs express CD29, CD44, CD49e, CD54, and CD13. CD29 (integrin $\beta-1$ ) is usually considered as a stem cell associated marker and its expression has been reported in several studies on neural stem cells [23], adipose-derived stem cells [24], cancer stem cells [25], and MSCs [26]. The CD49e molecule, also known as integrin $\alpha 5$, mediates cell adhesion and participates in cell-surface mediated signalling [27]. CD44 (H-CAM), a cell membrane glycoprotein involved in cell-cell interactions, cell adhesion and migration, is expressed on stem cell populations isolated from adipose tissue [24], bone marrow [28], astrocyte precursor cells [29], and hemopoietic stem cells [30]. The CD13 protein, a zincmetallopeptidase that cleaves single neutral amino acids, is expressed not only on the surface of early committed granulocyte and monocyte progenitors and endothelial cells, but also on BM stromal cells [31]. CD54 (ICAM-1, intercellular adhesion molecule-1) is constitutively expressed at low level in MSCs and the role it plays in stromal-induced immunosuppresion remains unknown [32].

Contradictory results have been obtained on the expression of CD106 (VCAM-1), a cell surface sialoglyco- 
Table 1. Phenotype of hUC Cells Obtained from the Subendothelial Layer of the Umbilical Vein

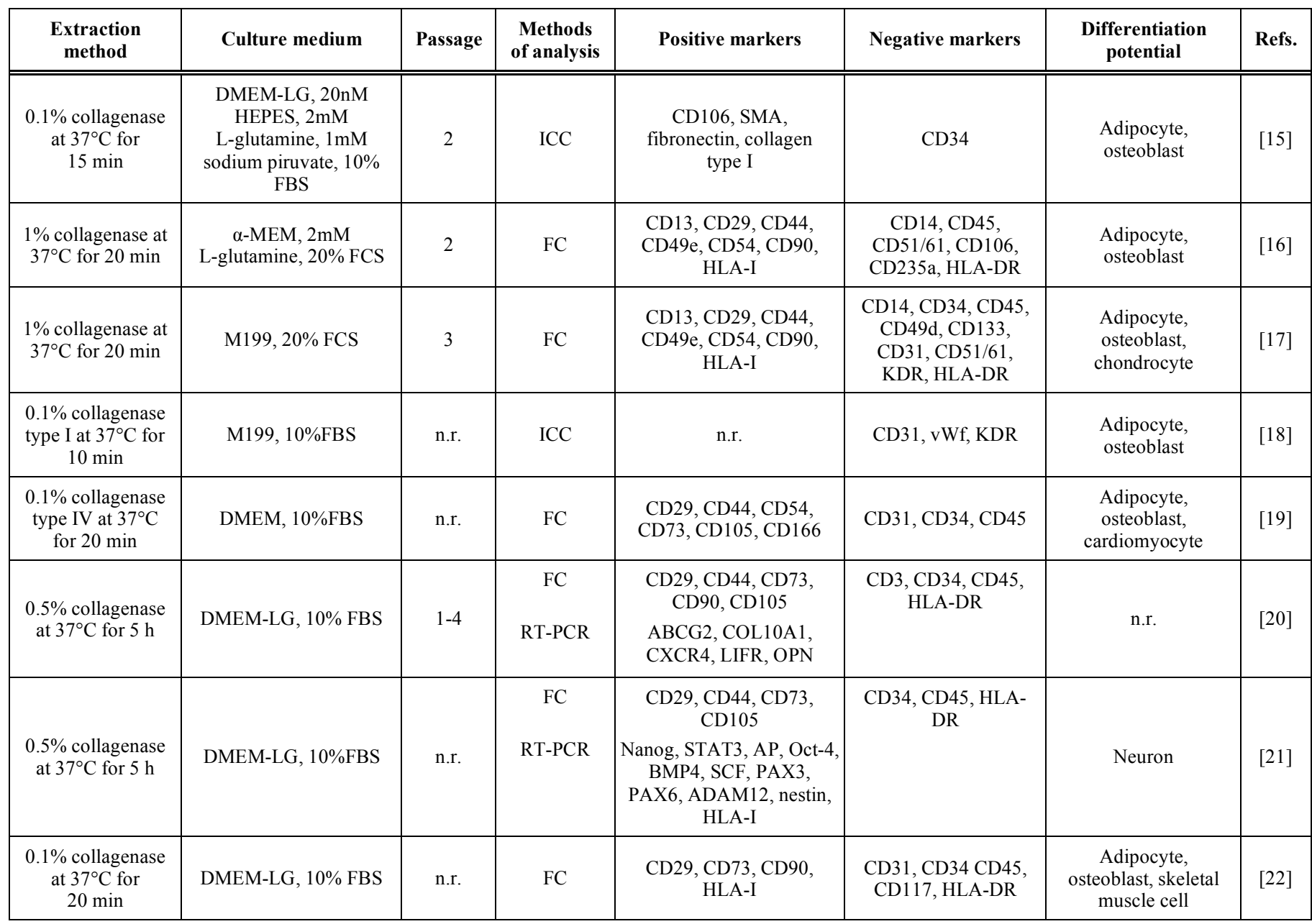

ICC: immunocytochemistry; FC: flow cytometry; n.r.: not reported.

protein belonging to the immunoglobulin superfamily [32]: Romanov et al., [15], but not Covas et al., [16], reported the immunoreactivity against this marker. RT-PCR revealed the expression, as mRNAs, of molecules of the undifferentiated state [Nanog, Oct-4, leukemia inhibitory factor receptor (LIFR), and ABCG2], mesoderm (CXCR4, CD44), and extracellular matrix (collagen) [20, 21]. Nanog and Oct-4 (octamer-binding transcription factor-4), also known as POU5F1 (POU domain, class 5, transcription factor 1), are involved in self-renewal of undifferentiated embryonic stem cells [33]. According to various reports, the expression of these markers are not restricted to embryonic stem cells, but also to stem cells isolated from umbilical cord, adipose tissue or induced pluripotent stem cells [33].

It has been demonstrated that MSCs from the subendothelial layer can differentiate in vitro into adipogenic, osteogenic, chondrogenic and myogenic (skeletal and cardiac muscle) lineages. Interestingly, nestin and PAX6, related to early differentiation of neuronal ectoderm, were found in MSCs, suggesting that these cells may be easily differentiated into neuronal lineage [21]. Nevertheless, these cells fail to differentiate in vitro into functional active neurons. Thus, the improvement of neurobehavorial function and the reduction of the infarct volume observed after injection of
hUC-MSCs in ischemic stroke rats seemed to be related to the secretion of neutrotrophic factors rather then the integration of these cells into the host nervous system [21].

\subsection{MSCs from the Perivascular Zone}

UC vessels are isolated together with their surrounding matrix and then sutured to form a loop, from which MSCs are obtained by enzymatic digestion at $37^{\circ} \mathrm{C}$ using collagenase $(0.5-1 \mathrm{mg} / \mathrm{mL})[34,35]$ or a cocktail composed of dispase, hyaluronidase, collagenase, and trypsin [36]. The incubation times are very variable ranging from 1 to $24 \mathrm{~h}$. Except for Farias et al., [36] which have used a culture media supplemented with growth factors, such as dexametasone, ascorbic acid, epidermal growth factor (EGF) and insulin, that may induce cell differentiation, the other Authors have cultured MSCs, previously depleted of CD45positive cells, with $\alpha$-MEM containing $15 \%$ FBS [34, 35, 37]. The phenoypic profile of MSCs from the perivascular zone seems to resemble, at least in part, that of the subendothelial layer. Indeed, cells express, as protein, CD105, CD73, CD90, CD29, CD44, and CD54, but lack Oct-4 (Table 2). Moreover, the presence of CD10 and CD68, not reported for cells of the subendothelial layer, has been verified. The 
Table 2. Phenotype of hUC Cells Obtained from the Perivascular Zone

\begin{tabular}{|c|c|c|c|c|c|c|c|}
\hline Extraction method & Culture medium & Passage & $\begin{array}{l}\text { Methods } \\
\text { of analysis }\end{array}$ & Positive markers & Negative markers & $\begin{array}{l}\text { Differentiation } \\
\text { potential }\end{array}$ & Refs. \\
\hline $\begin{array}{l}1 \mathrm{mg} / \mathrm{mL} \text { collagenase at } \\
37^{\circ} \mathrm{C} \text { for } 18-24 \mathrm{~h}\end{array}$ & $\alpha$-MEM, $15 \%$ FBS & 2 & $\mathrm{FC}$ & $\begin{array}{l}\text { CD44, CD54, CD73, } \\
\text { CD90, CD105, } \\
\text { CD117, HLA-I }\end{array}$ & $\begin{array}{l}\text { CD34, CD45, } \\
\text { CD106, CD123, } \\
\text { CD235a, SSEA-4, } \\
\text { HLA-II, Oct-4 }\end{array}$ & Osteoblast & [37] \\
\hline $\begin{array}{l}1 \mathrm{mg} / \mathrm{mL} \text { collagenase at } \\
37^{\circ} \mathrm{C} \text { for } 4 \mathrm{~h}\end{array}$ & $\begin{array}{c}\alpha \text {-MEM, } 15 \% \text { FBS, } 1 \%, \text { L- } \\
\text { glutamine }\end{array}$ & $2-5$ & $\mathrm{FC}$ & $\begin{array}{c}\mathrm{CD} 29, \mathrm{CD} 44, \mathrm{CD} 73, \\
\text { CD90, CD105, } \\
\text { CD146 }\end{array}$ & $\begin{array}{l}\text { CD14, CD34, } \\
\text { CD45, CD106, } \\
\text { CD117 }\end{array}$ & $\begin{array}{l}\text { Adipocyte, } \\
\text { osteoblast, } \\
\text { chondrocyte }\end{array}$ & [34] \\
\hline $\begin{array}{l}0.5 \mathrm{mg} / \mathrm{mL} \\
\text { collagenase I at } 37^{\circ} \mathrm{C} \\
\text { for } 18-24 \text { hours }\end{array}$ & $\alpha-M E M, 15 \%$ FBS & $2-9$ & $\begin{array}{c}\text { FC } \\
\text { RT-PCR }\end{array}$ & $\begin{array}{l}\text { CD44, CD73, CD90, } \\
\text { CD105, CD106 } \\
\text { Collagen IA1, } \\
\text { Desmin, MyoD }{ }^{\text {Low }}\end{array}$ & $\mathrm{CD} 34, \mathrm{CD} 45$ & $\begin{array}{l}\text { Adipocyte, } \\
\text { osteoblast, } \\
\text { chondrocyte, } \\
\text { fibroblast, } \\
\text { skeletal muscle } \\
\text { cell }\end{array}$ & [35] \\
\hline $\begin{array}{c}1.38 \mathrm{mg} / \mathrm{mL} \text { dispase, } \\
0.2 \mathrm{mg} / \mathrm{mL} \\
\text { hyaluronidase, } 0.8 \\
\mathrm{mg} / \mathrm{ml} \text { collagenase } \mathrm{IV} \\
\text { for } 45 \mathrm{~min}(\mathrm{x} 2) \text { at } 37 \\
{ }^{\circ} \mathrm{C} \text { and } 0.25 \% \text { trypsin- } \\
\text { EDTA at } 37^{\circ} \mathrm{C} \text { for } 20 \\
\text { min }\end{array}$ & $\begin{array}{c}\text { 60\% DMEM-LG, } 2 \% \text { FBS, } \\
40 \% \text { MCDB-201, } 1 \mathrm{x} \text { insulin } \\
\text { transferrin selenium, } 1 \mathrm{x} \\
\text { linoleic acid-bovine serum } \\
\text { albumin, } 10^{-9} \mathrm{M} \\
\text { dexamethasone, } 10^{-4} \mathrm{M} \\
\text { ascorbic acid } 2-\text { phosphate, } \\
10 \mathrm{ng} / \mathrm{mL} \mathrm{EGF,} 10 \mathrm{ng} / \mathrm{mL} \\
\text { PDGF-BB }\end{array}$ & $3-5,9$ & FC & $\begin{array}{c}\text { CD10, CD29, CD44, } \\
\text { CD54, CD68, CD73, } \\
\text { CD90, CD105, } \\
\text { caldesmon, desmin, } \\
\text { SMA, CKAE1/AE3, } \\
\text { Ki67, podoplanin, } \\
\text { vimentin } \\
\text { CD10, CD14, CD29, } \\
\text { CD44, CD54, CD73, } \\
\text { CD90, CD105, SMA }\end{array}$ & $\begin{array}{l}\text { CD31, CD34, } \\
\text { CD45 } \\
\text { CD34, CD45 }\end{array}$ & n.r. & [36] \\
\hline
\end{tabular}

ICC: immunocytochemistry; FC: flow cytometry; n.r.: not reported.

protein CD10 is a surface enzyme with neutral metalloendopeptidase activity and able to inactivate a variety of biologically active peptides. It is expressed not only in B-cell lymphomas, but also in other cell types, such as BM-MSCs and human fibroblasts [38]. Farias et al., [36] has suggested that all cells from perivascular area derive from Wharton's jelly, as they are $100 \%$ positive for CD10, an in vivo expressed marker of Wharton's jelly cells, but not of amnion or arterial smooth muscle layers. During culturing, it is reported that the cells acquire the expression of CD68, a myelomonocytic marker, that is present on adipose tissuederived MSCs cultured under defined conditions [39]. The same Authors also reported that perivascular area cells resemble myofibroblasts, because of the expression of SMA and caldesmon and the capacity to contract under stimulation with trasforming growth factor (TGF)- $\beta 1$ and platelet derived growth factor (PDGF). Interestingly, Sarugaser et al., [37] have reported a cell population negative to both HLA class I and II that increases during the first five passages and after cryopreservation. These data are particularly attractive in view of their clinical application in cell-based therapies. Some discrepancies among the various studies exist about the immuno-reactivity against CD106 and CD117 [c-kit, stem cell factor (SCF) receptor] [34, 35, 37]. Surprisingly, Sarugaser et al., using the same extraction method, culture conditions and method of analysis, have reported that cells were positive to CD106 in one work [35] and negative in another one [37]. MSCs from the perivascular zone were reported to differentiate in vitro into osteoblastic, adipogenic, chondrogenic, myogenic and fibroblastic lineages [34, 35, 37]. Furthermore, when injected into the femoral marrow cavity of NOD-SCID mice, these cells produced bone, cartilage and fibrous stroma, suggesting that they can contribute to tissue repair in response to injury [36]. No expression of cardiac markers were detected after inductive treatment with 5-azacytidine [34].

\subsection{MSCs from the Wharton's Jelly}

Most of researchers use Wharton's jelly as a source of MSCs [3, 8, 40-63]. After removal of vessels, the mucous tissue is cut in small pieces and incubated at $37^{\circ} \mathrm{C}$ with enzymatic solution containing various types of collagenase and/or hyaluronidase, trypsin, and dispase (Table 3). Also here, incubation times greatly differ from one extraction protocol to another. Alternatively, the fragments are put in culture plates and cells are allowed to migrate from explants. Culture media are mainly composed of DMEM supplemented with $10-20 \%$ FBS or FCS, but MCDB 201, RPMI 1640, $\alpha-$ MEM, F12, and MesenCult have been also used. In a few works $[41,42,57]$ culture media have been enriched with growth factors, such as basic fibroblast growth factor (bFGF), PDGF, dexametasone, and ascorbic acid. The explant method may present some advantages because cell damage induced by the enzymatic treatment is avoided and the growth factors contained in Wharton's jelly may support the proliferation of MSCs. Primary cultures obtained by the explant method seem to be heterogeneous. Indeed, Majore et al., [47] have isolated by means of Counterflow Centrifugal Elutriation (CCE) a small-size (diameter about 11.1 $\mu \mathrm{m})$ cell population that exhibited higher proliferative rates and expression of MSC markers in respect to large-sized (diameter about $19 \mu \mathrm{m}$ ) cells. These data have suggested that small cells may represent precursors of the larger ones. Overall, cells from Wharton's jelly fit with the minimal criteria for MSCs. Nevertheless, Kadam et al., [52] have not found any expression of CD105, while Bakshi et al., [46] 
have observed that this marker is missing in cultures of earlier passages but is present at the 5th passage. The mesenchymal features of Wharton's jelly cells have been confirmed by the expression of specific lineage cytoskeletal markers, such as SMA [3, 43, 52] and vimentin $[3,52,61$, 62]. Furthermore, embryonic stem cell markers, such as Oct3/4, SSEA4, nucleostemin, SOX-2, and Nanog, have also been revealed [41, 56, 58, 60-63]. Other detected cell surface molecules, whose expression has not been verified on MSCs from UC subendothelial layer and perivascular zone, are CD59 [41] and CD146 [34, 48, 62]. CD59 is involved in the complement system regulation: it inhibits the formation of pore forming membrane attack complex thus preventing cell lysis. CD146, also known as cell surface glycoprotein MUC18, is a cell adhesion molecule expressed not only on endothelial cells but also on MSCs. As reported in Table 1, the protein CD51 or vitronectin receptor, member of the integrin family, was not found on MSCs from the subendothelial layer $[16,17]$. It is unlikely that MSCs from Wharton's jelly demonstrated to be positive to this marker $[40,49]$.

Regarding to the immunomodulatory properties of MSCs from Wharton's jelly, it has been demonstrated that cells, such as plancental ones, express the HLA-G6 isoform [8]. HLA-G seems to play a role in the immune tollerance during pregnancy avoiding a maternal immune response against the

Table 3. Phenotype of hUC Cells Obtained from Wharton's Jelly

\begin{tabular}{|c|c|c|c|c|c|c|c|}
\hline Extraction method & Culture medium & Passage & $\begin{array}{l}\text { Methods } \\
\text { of analysis }\end{array}$ & Positive markers & $\begin{array}{l}\text { Negative } \\
\text { markers }\end{array}$ & $\begin{array}{l}\text { Differentiation } \\
\text { potential }\end{array}$ & Refs. \\
\hline $\begin{array}{c}2 \mathrm{mg} / \mathrm{mL} \text { collagenase for } \\
16 \mathrm{~h}, 2.5 \% \text { trypsin for } \\
30 \mathrm{~min} \text { at } 37^{\circ} \mathrm{C}\end{array}$ & $\begin{array}{l}\text { DMEM-HG, } \\
10 \% \mathrm{FBS}\end{array}$ & 1 & $\mathrm{FC}$ & $\begin{array}{c}\text { CD29, CD44, CD51, CD73, } \\
\text { CD105 }\end{array}$ & CD34, CD45 & $\begin{array}{l}\text { Adipocyte, } \\
\text { osteoblast, } \\
\text { chondrocyte, } \\
\text { cardiomiocyte }\end{array}$ & {$[40]$} \\
\hline Explants & $\begin{array}{c}\text { DMEM, } 10 \% \text { FBS, } \\
\text { 5ng/mL bFGF, } 5 \\
\text { ng/mL EGF }\end{array}$ & $3-8$ & $\mathrm{FC}$ & CD29, CD44, CD59 & $\begin{array}{l}\text { CD14, CD 33, } \\
\text { CD34, CD 38, } \\
\text { CD40, CD40L, } \\
\text { CD45, CD 80, } \\
\text { CD86, CD117 }\end{array}$ & $\begin{array}{l}\text { Adipocyte, } \\
\text { osteoblast, } \\
\text { neuron }\end{array}$ & {$[41]$} \\
\hline $\begin{array}{l}\text { Hyaluronidase, trypsin, } \\
\text { and collagenase at } 37^{\circ} \mathrm{C} \\
\text { for } 45-60 \mathrm{~min}\end{array}$ & $\begin{array}{l}\text { 56\% DMEM-LG, } \\
\text { 37\% MCBD 201, 2\% } \\
\text { FBS, 1x insulin- } \\
\text { transferrin-selenium } \\
\text { A, } 10 \mathrm{nM} \\
\text { dexametasone, } 50 \mu \mathrm{M} \\
\text { ascorbic acid, } 10 \\
\text { ng/mL PDGF-BB }\end{array}$ & $4-8$ & $\begin{array}{c}\text { FC } \\
\text { gene array }\end{array}$ & $\begin{array}{c}\text { CD10, CD13, CD29, CD44, } \\
\text { CD49e, CD90, CD105, HLA-I } \\
E S G 1, S O X-2, T E R T, S H H, \\
\text { neuregulin-1 and 4, Patched, } \\
S N A 2, W N T 4, \text { N-cadherin, V- } \\
\text { cadherin, R-cadherin, integrin- } \\
\beta_{1} \text {, integrin- } \alpha \text {, VCAM-1, } \\
\text { CD49b, integrin- } \alpha_{\mathrm{V}}, \text { integrin- } \\
\beta_{5}, \text { integrin- } \alpha_{4}, \text { era, CNTF, } \\
V E G F, F G F 20, T R K C, \\
\text { ACTG2, ACTA2, BMP1, } \\
\text { PDGFB, CK 8, insulin }\end{array}$ & $\begin{array}{l}\text { CD14, CD } 31, \\
\text { CD34, CD45, } \\
\text { CD56, CD133, } \\
\text { HLA-DR }\end{array}$ & Neuron & {$[42]$} \\
\hline $\begin{array}{l}\text { Explants and immuno- } \\
\text { separated CD105+/ } \\
\text { CD31-/KDR-cells }\end{array}$ & $\begin{array}{l}\text { DMEM-LG, } 20 \% \\
\text { FBS }\end{array}$ & $\begin{array}{l}\text { CD105+ } \\
\text { CD31- } \\
\text { KDR- }\end{array}$ & ICC & CD90, HLA-I, SMA & $\begin{array}{l}\text { CD34, CD38, } \\
\text { CD45, CD54, } \\
\text { SREBP, MYF5 }\end{array}$ & $\begin{array}{c}\text { Adipocyte, } \\
\text { osteoblast, skeletal } \\
\text { muscle cells }\end{array}$ & {$[43]$} \\
\hline $\begin{array}{l}\text { Collagenase type I at } \\
37^{\circ} \mathrm{C} \text { for } 14-18 \mathrm{~h}\end{array}$ & DMEM, $10 \%$ FCS & $4-8$ & FC & $\begin{array}{l}\text { CD13, CD29, CD44, } \\
\text { CD49b, CD73, CD90, } \\
\text { CD105, CD166, HLA-I }\end{array}$ & $\begin{array}{c}\text { CD1q, CD3, CD10, } \\
\text { CD14, CD31, } \\
\text { CD34, CD45, } \\
\text { CD49a, CD56, } \\
\text { CD117, HLA-DR }\end{array}$ & $\begin{array}{l}\text { Adipocyte, } \\
\text { osteoblast, } \\
\text { neuron }\end{array}$ & {$[44]$} \\
\hline Explants & $\begin{array}{l}\text { RPMI } 1640,20 \% \\
\text { FBS }\end{array}$ & 2 & $\mathrm{FC}$ & $\begin{array}{l}\text { CD29, CD } 44, \text { CD } 49 b, \\
\text { CD58, CD 73, CD105, } \\
\text { CD166, HLA-I }\end{array}$ & $\begin{array}{c}\text { CD3, CD7, CD14, } \\
\text { CD19, CD33, } \\
\text { CD34, CD40, } \\
\text { CD45, CD49d, } \\
\text { CD80, CD86, } \\
\text { CD117, CD133, } \\
\text { HLA-DR, 3G5, } \\
\text { STRO-1 }\end{array}$ & n.r & {$[45]$} \\
\hline $\begin{array}{c}1 \mathrm{mg} / \mathrm{mL} \text { collagenase } \\
\text { type } \mathrm{I} \text { at } 37^{\circ} \mathrm{C} \text { for } \\
18-24 \mathrm{~h}\end{array}$ & $\begin{array}{l}\text { DMEM-LG, } 10 \% \\
\text { FBS }\end{array}$ & 4 & $\begin{array}{l}\text { ICC, FC, } \\
\text { RT-PCR }\end{array}$ & $\begin{array}{c}\text { CD13, CD29, CD29b, } \\
\text { CD44, CD49e, CD54, } \\
\text { CD73, CD90, CD105, } \\
\text { CD117 }{ }^{\text {low }} \text {, CD166, HLA-I, } \\
\text { SMA, vimentin, fibronectin }\end{array}$ & $\begin{array}{l}\text { CD14, CD34, } \\
\text { CD45, CD140a, } \\
\text { HLA-II }\end{array}$ & $\begin{array}{l}\text { Adipocyte, } \\
\text { osteoblast, } \\
\text { hepatocyte }\end{array}$ & [3] \\
\hline $\begin{array}{l}\text { Hyaluronidase, trypsin, } \\
\text { and collagenase at } 37^{\circ} \mathrm{C} \\
\text { for } 45-60 \mathrm{~min}\end{array}$ & & 4 & $\begin{array}{c}\text { FC } \\
\text { RT-PCR }\end{array}$ & HLA-G6 & $\begin{array}{l}\text { CD40, CD80, } \\
\text { CD86 } \\
\text { HLA-G5 }\end{array}$ & n.r. & [8] \\
\hline
\end{tabular}


(Table 3) Contd....

\begin{tabular}{|c|c|c|c|c|c|c|c|}
\hline Extraction method & Culture medium & Passage & $\begin{array}{l}\text { Methods } \\
\text { of analysis }\end{array}$ & Positive markers & $\begin{array}{l}\text { Negative } \\
\text { markers }\end{array}$ & $\begin{array}{l}\text { Differentiation } \\
\text { potential }\end{array}$ & Refs. \\
\hline $\begin{array}{l}1 \mathrm{mg} / \mathrm{mL} \text { collagenase } \\
\text { type I at room } \\
\text { temperature for } 18-24 \mathrm{~h}\end{array}$ & $\begin{array}{l}\text { DMEM-LG, } 2 \mathrm{mM} \\
\text { glutamine, } 10 \% \mathrm{FBS}\end{array}$ & $3-13$ & $\mathrm{FC}$ & $\begin{array}{l}\text { CD29, CD44, CD73, CD90, } \\
\text { CD105, CD166, HLA-I }\end{array}$ & $\begin{array}{l}\text { CD34, CD38, } \\
\text { CD45, CD117, } \\
\text { HLA-DR }\end{array}$ & n.r. & {$[46]$} \\
\hline Explants & $\begin{array}{l}\alpha \text {-MEM, } 15 \% \text { FBS, } \\
1 \% \text { L-glutamine }\end{array}$ & 2 & FC & $\begin{array}{c}\text { CD29, CD44, CD73, CD90, } \\
\text { CD105, CD146 }\end{array}$ & $\begin{array}{l}\text { CD14, CD34, } \\
\text { CD45, CD106, } \\
\text { CD117 }\end{array}$ & $\begin{array}{l}\text { Adipocyte, } \\
\text { osteoblast, } \\
\text { chondrocyte }\end{array}$ & {$[34]$} \\
\hline Explants + CCE & $\begin{array}{l}\text { MEM, } 15 \% \text { of human } \\
\text { serum }\end{array}$ & n.r. & FC & $\begin{array}{l}\text { CD44, CD73, CD90, } \\
\text { CD105 }\end{array}$ & CD34, CD45 & n.r. & {$[47]$} \\
\hline Explants & DMEM, $20 \%$ FCS & $1-10$ & $\mathrm{FC}$ & $\begin{array}{c}\text { CD44, CD73, CD90, } \\
\text { CD105, CD144 }{ }^{\text {low }}, \text { CD146, } \\
\text { HLA-I }\end{array}$ & CD34, CD45 & Osteoblast & {$[48]$} \\
\hline Explants & DMEM, 10\% FBS & $8-10$ & FC & $\begin{array}{c}\text { CD29, CD } 44, \text { CD 51, CD73, } \\
\text { CD105 }\end{array}$ & n.r. & n.r. & [49] \\
\hline $\begin{array}{c}0.2 \mathrm{mg} / \mathrm{mL} \text { collagenase } \\
\text { type I for } 24 \mathrm{~h} \text { and } 0.2 \% \\
\text { trypsin for } 30 \mathrm{~min} \text { at } 37^{\circ} \mathrm{C}\end{array}$ & $\begin{array}{l}\text { DMEM-HG, } \\
10 \% \mathrm{FBS}\end{array}$ & n.r. & ICC & $\begin{array}{c}\text { CD44, CD73, CD90, } \\
\text { CD105, CD106, CD144 }\end{array}$ & CD45 & n.r. & {$[50]$} \\
\hline Explants & $\begin{array}{l}\text { DMEM-LG, } 10 \% \\
\text { FBS }\end{array}$ & $3-4$ & $\mathrm{FC}$ & CD73, CD90, CD105 & CD14, CD45 & n.r. & {$[51]$} \\
\hline $\begin{array}{l}\text { Collagenase type IV and } \\
\text { dispase II for } 1 \mathrm{~h} \text { and } \\
\text { trypsin plus EDTA for } \\
30 \text { min at } 37^{\circ} \mathrm{C}\end{array}$ & $\begin{array}{l}\text { DMEM/F12 (1:1), } \\
\text { 10\% UC blood serum }\end{array}$ & 1 & $\begin{array}{l}\text { FC } \\
\text { ICC }\end{array}$ & $\begin{array}{l}\text { CD44, CD73, CD90, } \\
\text { CD117 } \\
\text { SMA, vimentin }\end{array}$ & $\begin{array}{l}\text { CD33, CD34 } \\
\text { CD45, CD105 }\end{array}$ & $\begin{array}{l}\text { Adipocyte, } \\
\text { osteoblast, } \\
\text { chondrocyte, } \\
\text { neuron }\end{array}$ & {$[52]$} \\
\hline $\begin{array}{c}2 \mathrm{mg} / \mathrm{mL} \text { collagenase at } \\
37^{\circ} \mathrm{C} \text { for } 16 \mathrm{~h}, 2.5 \% \\
\text { trypsin for } 30 \mathrm{~min} \text { at } 37^{\circ} \mathrm{C}\end{array}$ & $\begin{array}{l}\text { HMSCGM, growth } \\
\text { supplements }\end{array}$ & $\begin{array}{l}2,4,8 \\
12\end{array}$ & $\mathrm{FC}$ & $\begin{array}{l}\text { CD13, CD29, CD 73, CD90, } \\
\text { CD105, CD117, CD166 }\end{array}$ & $\begin{array}{l}\text { CD14, CD34, } \\
\quad \text { CD45 }\end{array}$ & $\begin{array}{l}\text { Adipocyte, } \\
\text { osteoblast, } \\
\text { chondrocyte }\end{array}$ & {$[53]$} \\
\hline $\begin{array}{l}\text { Collagenase }(300 \mathrm{U} / \mathrm{mL}) \\
\text { /hyaluronidase }(1 \\
\mathrm{mg} / \mathrm{mL}) \text { for } 1 \mathrm{~h}, 0.1 \% \\
\text { trypsin-EDTA solution } \\
\text { for } 30 \mathrm{~min}\end{array}$ & $\begin{array}{l}\text { Medium 1: Growth } \\
\text { Medium \#1 (GM\#1) } \\
\text { containing FBS; } \\
\text { Medium 2: StemPro } \\
\text { MSC SFM with 2\% } \\
\text { GMP-certified human } \\
\text { serum (SP+2\%HS); } \\
\text { Medium 3: MesenCult } \\
\text { ACF (MC) xeno- and } \\
\text { serum-free }\end{array}$ & n.r. & FC & CD73, CD90, CD105 & $\begin{array}{l}\text { CD34, CD } 45 \\
\text { CD80, CD86, } \\
\text { HLA-DR }\end{array}$ & $\begin{array}{l}\text { Adipocyte, } \\
\text { osteoblast, } \\
\text { endothelial cell }\end{array}$ & {$[54]$} \\
\hline Explants & $\begin{array}{l}\alpha \mathrm{MEM}, 15 \% \text { human } \\
\text { serum }\end{array}$ & $3-7$ & $\mathrm{FC}$ & $\begin{array}{l}\text { CD44, CD73, CD90, } \\
\text { CD105 }\end{array}$ & CD34, CD45 & n.r. & {$[55]$} \\
\hline $\begin{array}{l}\text { 1) Explant } \\
\text { 2) } 0.4 \% \text { collagenase } \\
\text { type II, } 0.01 \% \text { DNAse I } \\
\text { at } 37^{\circ} \mathrm{C} \text { for } 30 \mathrm{~min}\end{array}$ & $\begin{array}{c}\text { DMEM/F12 }(1: 1), \\
\text { GLUTAMAX }-\mathrm{I}, \\
\text { 10\% FBS, 40ng/mL } \\
\text { bFGF }\end{array}$ & from 3 & $\begin{array}{c}\text { FC } \\
\text { RT-PCR }\end{array}$ & $\begin{array}{c}\text { CD29, CD73, CD90, } \\
\text { CD105, HLA-I } \\
\text { Nanog, REX2, SOX-2, Oct-4 }\end{array}$ & $\begin{array}{l}\text { CD34, CD } 45 \\
\text { CD80, CD86, } \\
\text { HLA-DR }\end{array}$ & $\begin{array}{l}\text { Adipocyte, } \\
\text { osteoblast }\end{array}$ & {$[56]$} \\
\hline $\begin{array}{l}\text { Collagenase type I, } \\
\text { collagenase type IV and } \\
100 \text { IU hyaluronidase at } \\
37^{\circ} \mathrm{C} \text { for } 45 \mathrm{~min}\end{array}$ & $\begin{array}{l}\text { DMEM-HG, } 20 \% \\
\text { FBS, } 16 \mathrm{ng} / \mathrm{mL} \\
\text { bFGF, } 1 \mathrm{mM} \\
\text { L-glutamine, } 1: 200 \\
\text { dilution of insulin- } \\
\text { transferrin-selenium }\end{array}$ & 3 to 15 & $\begin{array}{l}\text { RT-PCR, } \\
\text { microarray }\end{array}$ & $\begin{array}{c}\text { CD10, CD13, CD29, CD } 44, \\
\text { CD73, CD90, CD105, } \\
\text { CD166, HLA-I }\end{array}$ & $\begin{array}{l}\text { CD14, CD11b, } \\
\text { CD18, CD } 31 \text {, } \\
\text { CD33, CD } 34, \\
\text { CD45, CD115, } \\
\text { vWf, CDH5, } \\
\text { ICAM-2, KDR, } \\
\text { FLT1, HLA-DR }\end{array}$ & n.r. & {$[57]$} \\
\hline $\begin{array}{l}1 \mu \mathrm{g} / \mathrm{mL} \text { collagenase } \\
\text { type B at } 37^{\circ} \mathrm{C} \text { for } 4 \mathrm{~h}\end{array}$ & $\begin{array}{c}\text { DMEM/F12 (1:1), } \\
10 \% \mathrm{FBS}\end{array}$ & $0-7$ & $\begin{array}{c}\text { FC, } \\
\text { RT-PCR }\end{array}$ & $\begin{array}{l}\text { CD29, CD73, CD90, } \\
\text { CD105, CD54, Nanog, } \\
\text { SOX-2, nucleostemin }\end{array}$ & $\begin{array}{l}\text { CD31, CD34, } \\
\text { CD45, CD133 }\end{array}$ & Adipocyte & {$[58]$} \\
\hline Explants & $\begin{array}{l}\text { DMEM-LG, } 10 \% \\
\text { FBS }\end{array}$ & 2 & $\mathrm{ICC}, \mathrm{FC}$ & $\begin{array}{l}\text { CD29, CD44, CD90, } \\
\text { CD105 }\end{array}$ & $\mathrm{CD} 34, \mathrm{CD} 45$ & $\begin{array}{c}\text { Adipocyte, } \\
\text { osteoblast, } \\
\text { Schwann-like cells }\end{array}$ & {$[59]$} \\
\hline $\begin{array}{l}500 \mathrm{mg} / \mathrm{mL} \text { collagenase } \\
\text { for } 20 \mathrm{~h}\end{array}$ & $\begin{array}{l}\text { KO-DMEM, } 10 \% \\
\text { FBS, } 2 \text { mM L- } \\
\text { glutamine }\end{array}$ & $3-8$ & $\mathrm{FC}$ & $\begin{array}{c}\text { CD54, CD73, CD90, CD95, } \\
\text { CD105, CD166, SSEA4, } \\
\text { HLA-I }\end{array}$ & $\begin{array}{l}\text { CD19, CD34, } \\
\text { CD45, CD50, } \\
\text { CD80, CD86, } \\
\text { HLA-DR }\end{array}$ & $\begin{array}{l}\text { Adipocyte, } \\
\text { osteoblast, } \\
\text { chondrocyte }\end{array}$ & {$[60]$} \\
\hline
\end{tabular}


(Table 3) Contd.....

\begin{tabular}{|c|c|c|c|c|c|c|c|}
\hline Extraction method & Culture medium & Passage & $\begin{array}{c}\text { Methods } \\
\text { of analysis }\end{array}$ & Positive markers & $\begin{array}{l}\text { Negative } \\
\text { markers }\end{array}$ & $\begin{array}{c}\text { Differentiation } \\
\text { potential }\end{array}$ & Refs. \\
\hline $\begin{array}{c}\text { Collagenase Type IV: } \\
\text { Dispase }(7: 1, \mathrm{v} / \mathrm{v}) \text { for } 30 \\
\text { min at } 37^{\circ} \mathrm{C}, 0.05 \%, \\
\text { trypsin and EDTA } \\
(0.02 \%) \text { for } 15-20 \text { min at } \\
37^{\circ} \mathrm{C}\end{array}$ & $\begin{array}{l}\text { DMEM: HF12 (1:1), } \\
\text { 10\% human UC blood } \\
\text { serum }\end{array}$ & $4-6$ & FC & $\begin{array}{l}\text { CD29, CD44, CD73, CD90, } \\
\text { CD117, Oct4 } \\
\text { nestin, vimentin, desmin, } \\
\text { SMA, Ki67, SSEA4 }\end{array}$ & $\begin{array}{l}\text { CD10, CD33, } \\
\text { CD34, CD45, } \\
\text { CD105, CD166, } \\
\text { HLA-DR }\end{array}$ & $\begin{array}{l}\text { Adipocyte, } \\
\text { osteoblast, } \\
\text { chondrocyte, } \\
\text { neuron, islet- } \\
\text { like cluster }\end{array}$ & {$[61]$} \\
\hline $\begin{array}{l}\text { Explants after } 1.2 \mathrm{U} / \mathrm{mL} \\
\text { dispase and } 112 \mathrm{U} / \mathrm{mL} \\
\text { type I collagenase (for } \\
\text { three } 5 \text {-min periods) }\end{array}$ & DMEM, $10 \%$ FBS & n.r. & RT-PCR & $\begin{array}{l}\text { CD29, CD44, CD73, CD90 } \\
\text { Nanog, Oct-3/4, SOX-2, } \\
\text { SOX-9 }\end{array}$ & $\mathrm{CD} 34, \mathrm{CD} 45$ & $\begin{array}{l}\text { Adipocyte, } \\
\text { osteoblast, } \\
\text { chondrocyte, } \\
\text { neuron, skeletal } \\
\text { muscle cell }\end{array}$ & {$[63]$} \\
\hline
\end{tabular}

ICC: immunocytochemistry; FC: flow cytometry; n.r.: not reported.

fetus. Compelling evidence has shown that the low rate of rejection seems to be associated to the expression of these antigens in blood and heart and liver/kidney grafts [64]. Furthermore, MSCs lack both CD80 and CD86 proteins [8, $41,45,54,56,60]$. CD80, present on activated B cells and monocytes, and CD86, found on antigen-presenting cells, are costimulatory molecules inducing $\mathrm{T}$ cell activation and survival. The simultaneous presence of HLA-G and the lack of CD80 and CD86 suggest that Wharton's jelly-derived MSCs are particularly suitable for cell-based therapy, in accordance with the in vivo studies where the transplantation of heterologous MSCs did not elicit acute rejection [7]. Finally, contradictory findings have been obtained on the expression of CD106 [34, 50], CD117 [3, 34, 41, 44-46, 53, 61], and nestin [61, 62].

MSCs from Wharton's jelly seem to possess a greater differentiation potential than ones obtained from the subendothelial layer, the perivascular zone, and the umbilical cord lining (see above). Indeed, they can differentiate into not only mesodermic but also ecto- and endodermic lineages. Weiss et al., [42] have shown that, after neural induction, MSCs express tyrosine hydroxylase, a marker for catecholaminergic neurons. The transplantation of undifferentiated hMSCs into the brain of hemiparkinsonian rats induced a behavioral recovery of the animals, suggesting the potential use of these cells for the treatment of central nervous system diseases. Furthermore, they may also contribute to nerve repair in clinical applications because they can differentiate in vitro into Schwann-cell lineage [59]. In a rat brain ischemia/riperfusion model, the transplantation of MSCs improved the neurological function and the cortical neuronal activity [44]. These effects were related not only to the differentiation of the transplanted cells into glial and neuronal cells, but also into endothelial cells. This latter differentiation potential may have implications for the therapy of vascular diseases. Indeed, when differentiated MSCs were transplated into wire-injured femoral arteries in mice, a quick re-endothelization and inhibition of neointimal hyperplasia were observed [50]. These effects were probably mediated by the pigment epithelium-derived growth factor (PEDF) that inhibits smooth muscle cell proliferation and possesses antioxidant properties. It has been demonstrated that MSCs from Wharton's jelly can also form mature islets, responsive to glucose challenge and expressing all the islet hormones
[61]. When immunoisolatory biocompatible capsules containing differentiated MSCs were transplanted in experimental diabetic mice, normoglycemia was restored indicating the functionality of these cells. Campard et al., [3] have shown that MSCs from Wharton's jelly constitutively express some markers of hepatic lineage, such as albumin, $\alpha$ fetoprotein, and cytokeratin-19. Although the production of urea and storing of glycogen were detected under differentiative medium, the cells fail to form in vitro mature hepatocytes. Nevertheless, undifferentiated MSCs injected into the spleen of partially hepatectomized SCID mice engrafted into the liver and express albumin and $\alpha$-fetoprotein.

Apart from their wide differentiation potential, MSCs from Wharton's jelly present some interesting characteristics not related to the replacement of injured cells. Indeed, they support the growth and the maintenance of hematopoietic stem cells from UC blood (UCB) through the production of hematopoietic growth factors $[45,46]$. Consistent with their immunomodulatory properties [5], they also enhance human hematopoietic engraftment in SCID mice when co-transplanted with hematopoietic stem cells [45]. MSCs from Wharton's jelly possess also antifibrotic properties. The administration of MSCs in a bleomycin-induced mouse model of lung injury reduced the inflammation and collagen concentration in the lung [48]. Interestingly, injected MSCs were detected only in areas of inflammation and fibrosis but not in healthy lung tissue. Similar results were obtained in a rat model of carbon tetrachloride-induced liver fibrosis [49]. Although the transplanted MSCs did not differentiate into hepatocytes, they secreted bioactive cytokines promoting liver cell repair through the reduction of hepatic inflammation.

\subsection{MSCs from the Umbilical Cord Lining}

Cells from the umbilical cord lining (UCL) have also been isolated by means of explant method after separation and dissection of the UCL membrane [65, 66]. Different cell populations have been obtained depending on the culture medium (Table 4). Gonzales et al., [65], using DMEM supplemented with $15 \%$ FBS, have characterized MSCs that expressed pluripotent markers, such as Nanog, Oct-4, and SSEA-4 and were able to differentiate into osteogenic, adipogenic, chondrogenic, cardiogenic, and neurogenic linea- 
Table 4. Phenotype of hUC Cells Obtained from the Umbilical Cord Lining

\begin{tabular}{|c|c|c|c|c|c|c|c|}
\hline $\begin{array}{l}\text { Extraction } \\
\text { method }\end{array}$ & Culture medium & Passage & $\begin{array}{l}\text { Methods of } \\
\text { analysis }\end{array}$ & Positive markers & $\begin{array}{l}\text { Negative } \\
\text { markers }\end{array}$ & $\begin{array}{l}\text { Differentiation } \\
\text { potential }\end{array}$ & Refs. \\
\hline Explants & $\begin{array}{c}\text { DMEM, } 15 \% \text { FBS, } \\
\text { Glutamax, MEM-non } \\
\text { essential aminoacids, MEM } \\
\text { vitamins }\end{array}$ & from 1 & $\begin{array}{l}\text { ICC, FC, } \\
\text { RT-PCR }\end{array}$ & $\begin{array}{c}\text { CD14, CD44, CD73, CD90, } \\
\text { CD105, CD106, CD166, } \\
\text { STRO-1, SSEA-4, HLA-I, } \\
\text { LIN, Nanog, Oct-4 }\end{array}$ & $\begin{array}{l}\text { CD19, CD34, } \\
\text { CD45, CD117, } \\
\text { CD133, HLA- } \\
\text { DR, SOX-2 }\end{array}$ & $\begin{array}{l}\text { Adipocyte, osteoblast, } \\
\text { chondrocyte, } \\
\text { cardiomiocyte, and } \\
\text { neuron }\end{array}$ & {$[65]$} \\
\hline Explants & $\begin{array}{l}\text { PTTe-1 medium, } 2.5 \% \text { FBS, } \\
50 \mu \mathrm{g} / \mathrm{mL} \text { insulin-like } \\
\text { growth factor- } 1,50 \mu \mathrm{g} / \mathrm{mL} \\
\text { PDGF-BB, } 5 \mu \mathrm{g} / \mathrm{mL} \\
\text { TGF- } \beta 1,5 \mu \mathrm{g} / \mathrm{mL} \text { insulin }\end{array}$ & up to 20 & $\begin{array}{c}\text { ICC, } \\
\text { RT-PCR }\end{array}$ & $\begin{array}{c}\text { CD34, CD45, CD73, CD105, } \\
\text { CD151, CD166, HLA-I, } \\
\text { CD227 } \\
\text { vimentin, E-cadherin, CK7, } \\
\text { CK14, CK19, Oct-4, Nanog, } \\
\text { SSEA-4, SOX-2, REX1, p63 }\end{array}$ & CD31, HLA-II & Epithelial cells & {$[66]$} \\
\hline
\end{tabular}

ICC: immunocytochemistry; FC: flow cytometry

ges. Interestingly, these cells also expressed CD14, that is a component of the innate immune system and they are present on macrophages, neutrophil granulocytes, and dendritic cells [67]. On the other hand, Reza et al., [66] have grown UCL cells in PTTe-1 medium containing components that preferentially support epithelial cell growth. As a result, a cell population possessing properties of both epithelial cells and embryonic stem cells has been obtained. Indeed, the cells highly expressed MUCIN1, whose function is to protect the epithelium by binding to pathogens [68], CD151, involved in epithelial cell-to-cell adhesion [69], p63, an adult epithelial stem cell marker [70], and CK7, CK14 and CK19 in varying degrees. Furthermore, cells were positive to several embryonic stem cell markers, such as Oct-4, Nanog, ring-exported protein-1 (REX-1), SOX-2, telomerase reverse transcriptase (TERT), and SSEA-4.

\subsection{MSCs from whole Umbilical Cord}

Starting from the presence of MSCs in many parts of hUC, several research groups have used whole hUC in the attempt to increase the yield of MSCs (Table 5) [71]. After mechanical chopping, explant culture of the cord is carried out or UC fragments are incubated at $37^{\circ} \mathrm{C}$ with various types of collagenase $(0.1 \%$ or $0.075 \%, \mathrm{w} / \mathrm{v})$ and trypsin $(0.25 \%$ or $0.125 \%, \mathrm{w} / \mathrm{v})[2,4,72-80]$. Also in this case, the incubation times greatly differ from one laboratory to another, ranging from $10 \mathrm{~min}$ to $3 \mathrm{~h}$. The most frequently used culture medium is DMEM-LG supplemented with $10 \%$ FBS or FCS. However, growth factors, such as vascular endothelial growth factor (VEGF), EGF, and bFGF, have been also added [72, 76, 79]. A comparison between the explant method and enzymatic digestion was carried out by Schugar et al., [81], which demonstrated that the isolation method affects population phenotype. Indeed, collagenase digestion lead to a cell population characterized by higher levels of MSC surface markers compared to that detected in cultures obtained by means of explant method or dispase digestion.

Although there is a wide heterogeneity of markers used to characterize the cells, MSCs from whole hUC express most of CD proteins detected in hUC cells from the subendothelial layer, perivascular area, umbilical cord lining, and Wharton's jelly (Table 5). Jo et al., [76] have shown that pluripotent stem cell markers, such as Oct-4, SSEA-3, SSEA-4, Tra-1-60, and Tra-1-81, are expressed, as both
mRNA and protein, by MSCs from the whole cord and their expression levels are maintained up to the $9^{\text {th }}$ passage. Furthermore, Qiao et al., [75] have detected nucleostemin, a p52 binding protein localized in nucleoli of stem cells [82], and BMI-1 involved in self-renewal [83], whereas La Rocca et al., [77] have demonstrated, for the first time, the presence of both isoforms of Oct-4 (A and B). The same Authors have extensively studied this cell population, verifying the expression of several markers related to the tumor cells, the immune recognition of MSCs by the immune system, neuroectodermal and endodermal differentiation. MSCs lack the expression of the carcino-embryonic antigen (CEA) [84] and an embryonic form of the Ras oncogene, known as Eras [85], suggesting that these cells could be used in cell therapy without any risk of tumorigenicity. As already reported for Wharton's jelly cells, the expression of HLA-G and the absence of CD86 have been detected. In addition to the presence of mesenchymal markers, such as vimentin, SMA, and prolyl-4-hydroxylase, neuroectodermal and endodermal markers have been revealed, confirming that these cells possess differentiation potential towards these lineages. Indeed, MSCs were positive to GATA-4, a transcription factor involved in cardiomyocyte differentiation [86], and connexin-43, highly expressed in cardiomyocytes [87]. When MSCs were induced to cardiomyocyte differentiation, changes in cell morphology with formation of myotube structures were observed [4].

Furthermore, about $50 \%$ of cells expressed cytokeratins (CK) 8, 18, and 19, none of which have been previously detected in MSCs. The feasibility to differentiate MSCs into neuronal lineage, already proposed for cells isolated from the subendothelial layer [21], is here supported by the expression of nestin [77], nerve growth factor receptor [73], which plays a role in survival and differentiation of neuronal cells, and CD56, the neural cell adhesion molecule involved in neurite outgrowth and synaptic plasticity [76]. Consistent with these findings, MSC cultures presented a high percentage of neuron specific enolase-positive cells after neuronal induction [72]. As already demonstrated for MSCs from Wharton's jelly, also ones from whole cord are able to differentiate in vitro into endothelial cells [79] and in vivo into hepatocyte-like cells, improving the recovery of carbon tetrachloride-injured mouse liver [73].

Other markers recognized on MSCs from whole cord are involved in cell adhesion and migration: CD9, a cell surface glycoprotein which forms a complex with integrins, CD49b, 
Table 5. Phenotype of hUC Cells Obtained from whole UC

\begin{tabular}{|c|c|c|c|c|c|c|c|}
\hline $\begin{array}{l}\text { Extraction } \\
\text { method }\end{array}$ & $\begin{array}{l}\text { Culture } \\
\text { medium }\end{array}$ & Passage & $\begin{array}{l}\text { Methods } \\
\text { of analysis }\end{array}$ & Positive markers & Negative markers & $\begin{array}{l}\text { Differentiation } \\
\text { potential }\end{array}$ & Refs. \\
\hline $\begin{array}{l}\text { Collagenase type } \\
\text { II } 0.075 \% \text { for } 30 \\
\text { min, } 0.125 \% \\
\text { trypsin for } 30 \\
\text { min at } 37^{\circ} \mathrm{C}\end{array}$ & $\begin{array}{l}\text { DMEM-LG, } 5 \% \\
\text { FBS, } 10 \mathrm{ng} / \mathrm{mL} \\
\text { VEGF, } 10 \\
\text { ng/mL EGF }\end{array}$ & $2-6$ & $\mathrm{FC}$ & $\begin{array}{l}\text { CD13, CD29, CD44, CD73, } \\
\text { CD105, CD106, CD166, HLA-I }\end{array}$ & $\begin{array}{c}\text { CD14, CD31, CD34, } \\
\text { CD38, CD45, HLA- } \\
\text { DR }\end{array}$ & $\begin{array}{l}\text { Adipocyte, } \\
\text { osteoblast, neuron }\end{array}$ & {$[72]$} \\
\hline $\begin{array}{c}3 \mathrm{mg} / \mathrm{mL} \\
\text { collagenase } 1 \mathrm{~S} \text { at } \\
37^{\circ} \mathrm{C} \text { for } 3 \mathrm{~h}\end{array}$ & $\begin{array}{c}\alpha \mathrm{MEM} / \mathrm{F} 12 \\
(1 / 1), 10 \% \\
\text { FBS }\end{array}$ & n.r. & ICC, FC & CD29, CD49b, CD73, CD105 & CD31, CD34, CD38 & Cardiomiocyte & [4] \\
\hline Explants & $\begin{array}{l}\text { DMEM-LG, } \\
10 \% \text { FBS }\end{array}$ & 2 & $\mathrm{FC}$ & $\begin{array}{l}\text { CD13, CD29, CD44, } \\
\text { CD105, NGFR }\end{array}$ & $\begin{array}{l}\text { CD34, CD38, CD45, } \\
\text { CD71, HLA-DR }\end{array}$ & $\begin{array}{l}\text { Adipocyte, } \\
\text { osteoblast }\end{array}$ & {$[73]$} \\
\hline Explants & $\begin{array}{l}\text { DMEM-LG, } \\
10 \% \text { FBS }\end{array}$ & 2 & $\mathrm{FC}$ & $\begin{array}{l}\text { CD13, CD44, CD73, } \\
\text { CD105, HLA-I }\end{array}$ & $\begin{array}{l}\text { CD14, CD31, CD45, } \\
\text { CD144, HLA-DR }\end{array}$ & $\begin{array}{l}\text { Adipocyte, } \\
\text { osteoblast, } \\
\text { chondrocyte }\end{array}$ & {$[74]$} \\
\hline $\begin{array}{l}0.1 \% \text { collagenase } \\
\text { for } 2 \mathrm{~h} \text { and } \\
0.25 \% \text { trypsin for } \\
1 \mathrm{~h} \text { at } 37^{\circ} \mathrm{C}\end{array}$ & $\begin{array}{l}\text { DMEM-LG, } \\
10 \% \text { FBS, } 10 \\
\text { ng/mL bFGF }\end{array}$ & $2,5,7,9$ & $\begin{array}{l}\text { ICC, RT- } \\
\text { PCR }\end{array}$ & $\begin{array}{c}\text { CD9, CD10, CD13, CD29, CD44, } \\
\text { CD49a, CD49b, CD54, CD56, CD62e, } \\
\text { CD68, CD73, CD90, CD105, CD117, } \\
\text { CD120, CD133, CD166, CD235a, } \\
\text { HLA-I } \\
\text { Nanog, Oct-4, SSEA-3, SSEA-4, Tra- } \\
\text { 1-60, Tra-1-81 }\end{array}$ & $\begin{array}{l}\text { CD11, CD14, CD31, } \\
\text { CD34, CD40, CD45, } \\
\text { CD66, CD71, CD106, } \\
\text { STRO-1, HLA-DR }\end{array}$ & $\begin{array}{l}\text { Adipocyte, } \\
\text { osteoblast, } \\
\text { chondrocyte }\end{array}$ & {$[76]$} \\
\hline Explants & $\begin{array}{l}\text { DMEM-LG, } \\
10 \% \text { FCS, } 1 \mathrm{x} \\
\text { non essential } \\
\text { aminoacids }\end{array}$ & up to 15 & $\begin{array}{l}\text { ICC, } \\
\text { RT-PCR }\end{array}$ & $\begin{array}{c}\text { CD10, CD13, CD29, CD44, CD73, } \\
\text { CD80, CD90, CD105, CD106, } \\
\text { CD117, CD133, CD166, Oct-1, } \\
\text { Oct-4 (A and B), HLA-A, HLA-G, } \\
\text { Nanog, GATA-4/5/6, SMA, } \\
\text { vimentin, nestin, CKs 8/18/19, } \\
\text { connexin-43, GFAP, NSE, HNF- } \\
4 \alpha, \text { Prolyl-4-Hydroxylase }\end{array}$ & $\begin{array}{c}\text { CD31,CD33, CD34, } \\
\text { CD38, CD45, CD79, } \\
\text { CD86, CEA, HLA-DR, } \\
\text { ERas, CK7, MyoD, } \\
\text { Myosin (smooth } \\
\text { muscle), vWf, Oct-2 }\end{array}$ & $\begin{array}{l}\text { Adipocyte, } \\
\text { osteoblast }\end{array}$ & {$[77]$} \\
\hline $\begin{array}{c}0.1 \% \\
\text { collagenase at } \\
37^{\circ} \mathrm{C} \text { for } 20 \mathrm{~min}\end{array}$ & $\begin{array}{l}\text { DMEM-LG, } \\
10 \% \text { FBS }\end{array}$ & n.r. & $\mathrm{FC}$ & $\begin{array}{c}\text { CD13, CD29, CD44, CD73, CD90, } \\
\text { HLA-I }\end{array}$ & $\begin{array}{l}\text { CD31, CD34, CD45, } \\
\text { CD117, HLA-DR }\end{array}$ & $\begin{array}{l}\text { Adipocyte, } \\
\text { osteoblast, } \\
\text { chondrocyte }\end{array}$ & {$[80]$} \\
\hline Explants & $\begin{array}{l}\text { DF- } 12,10 \% \\
\quad \text { FBS }\end{array}$ & up to 25 & $\mathrm{FC}$ & CD90, CD105, CD73 & n.r. & $\begin{array}{l}\text { Adipocyte, } \\
\text { osteoblast, } \\
\text { chondrocyte }\end{array}$ & [2] \\
\hline
\end{tabular}

ICC: immunocytochemistry; FC: flow cytometry; n.r.: not reported.

and integrin $\alpha$ subunit, and CD62, also known as E-selectin. As reported above for MSCs obtained from the various parts of hUC, contradictory results were obtained concerning the presence of CD106 and CD117. Finally, MSCs from whole cord have been shown to express cytokines, such as IL-6, SCF, Flt-3, granulocyte colony-stimulating factor (G-CSF) and granulocyte-macrophage colony-stimulating factor (GM$\mathrm{CSF}$ ), that are associated with hematopoietic stem cell proliferation, suggesting a potential hematopoiesis supportive function [72].

\subsection{Comparison between MSCs from Various Parts of hUC}

Table 6 summarizes the availability of some markers in MSCs obtained from the various parts of hUC. In the attempt to make a comparison among the UC cell phenotypes, only the markers studied in at least two separate cell populations have been reported. All MSCs seem to resemble each other. Indeed, they do not possess a hematopoietic profile, whereas mesenchymal and embryonic stem cell markers are exp- 
Table 6. Availability of Markers on hUC Cells by Flow Cytometry, Immunocytochemistry, RT-PCR, Gene Expression Assays

\begin{tabular}{|c|c|c|c|c|c|}
\hline Marker & $\begin{array}{c}\text { SE } \\
\text { cells }\end{array}$ & $\begin{array}{l}\text { PV } \\
\text { cells }\end{array}$ & $\begin{array}{l}\text { UCL } \\
\text { cells }\end{array}$ & $\begin{array}{l}\text { WJ } \\
\text { cells }\end{array}$ & $\begin{array}{l}\text { wUC } \\
\text { cells }\end{array}$ \\
\hline CD10 & n.r. & + & n.r. & $+/-$ & + \\
\hline CD13 & + & n.r. & n.r. & + & + \\
\hline $\mathrm{CD} 14$ & - & $+/-$ & + & - & - \\
\hline CD19 & n.r. & n.r. & - & - & - \\
\hline CD29 (integrin $\beta 1$ ) & + & + & n.r. & + & + \\
\hline CD31 (PECAM) & - & - & - & - & - \\
\hline CD34 & - & - & $+/-$ & - & - \\
\hline CD44 (HCAM) & + & + & + & + & + \\
\hline $\mathrm{CD} 45$ & - & - & $+/-$ & $+/-$ & - \\
\hline CD49a & n.r. & n.r. & n.r. & - & + \\
\hline CD49b (integrin $\alpha 2$ ) & n.r. & n.r. & n.r. & + & + \\
\hline CD49d (integrin $\alpha 4$ ) & - & n.r. & n.r. & - & n.r. \\
\hline CD49e (integrin $\alpha 3$ ) & + & n.r. & n.r. & + & n.r. \\
\hline CD54 (ICAM-1) & + & + & n.r. & $+/-$ & + \\
\hline CD73 (SH3) & + & + & + & + & + \\
\hline CD80 & n.r. & n.r. & n.r. & - & + \\
\hline CD86 & n.r. & n.r. & n.r. & - & - \\
\hline CD90 (Thy-1) & + & + & + & + & + \\
\hline CD105 (SH2) & + & + & + & $+/-$ & + \\
\hline CD106 (VCAM-1) & $+/-$ & $+/-$ & + & $+/-$ & $+/-$ \\
\hline CD117 (c-kit) & - & $+/-$ & - & $+/-$ & $+/-$ \\
\hline CD133 & - & n.r. & - & - & + \\
\hline CD166 (ALCAM) & + & n.r. & + & $+/-$ & + \\
\hline $\begin{array}{c}\text { CD235a } \\
\text { (glycophorin A) }\end{array}$ & - & - & n.r. & n.r. & + \\
\hline HLA-I & + & + & + & + & + \\
\hline HLA-G & n.r. & n.r. & n.r. & + & + \\
\hline HLA-DR & - & - & - & - & - \\
\hline Nanog & + & n.r. & + & + & + \\
\hline Nestin & + & n.r. & n.r. & $+/-$ & + \\
\hline nucleostemin & n.r. & n.r. & n.r. & + & + \\
\hline Oct-4 & + & - & + & + & + \\
\hline SMA & + & + & n.r. & + & + \\
\hline SOX-2 & n.r. & n.r. & $+/-$ & + & n.r. \\
\hline SSEA-4 & n.r. & - & + & + & + \\
\hline STRO-1 & n.r. & n.r. & + & $+/-$ & - \\
\hline vimentin & n.r. & + & + & + & + \\
\hline vWf & - & n.r. & n.r. & - & - \\
\hline
\end{tabular}

SE: subendothelial layer; PV: perivascular; UCL: umbilical cord lining; WJ: Wharton's jelly; wUC: whole umbilical cord; n.r. : not reported; +/-: contradictory results. ressed. Moreover, HLA class I, but not HLA class II, are present. Nevertheless, a different expression of some markers exists among the various hUC-MSCs. The CD133 and $\mathrm{CD} 235$ a proteins have been revealed in cells from the whole $\mathrm{UC}$, but not in those obtained from the other parts of the cord. The UCL cells and, at least in part, the perivascular cells express CD14 which has not been detected on cells isolated from the subendothelial zone, the Wharton's jelly, and whole UC. Other differences in stem cell markers, such as Oct-4, SSEA-4, and STRO-1, and integrins $\alpha$ are also visible. These findings suggest that the each part of hUC may contain a MSC population that differs from those of the other parts. Furthermore, different cell types could be contained within the same part of UC because of the discrepancies in marker expression. However, it seems impossible to draw a conclusion starting from the available data obtained by means of high heterogeneous protocols. To verify whether hUC-MSCs could represent an unique cell population or a family composed of cells at different stemness and/or committed degrees, a great effort must be made through the various research groups to standardize extraction methods, culture media, and conditions and analysis output. Indeed, phenotype characterization should be carried out using the same culture passage and a more homogenous panel of markers. The percentage of the expression should also be assessed. Furthermore, the in situ identification of stem cell niche and MSCs inside the cord could be very useful. In this context, Schugar et al., [81] have demonstrated that CD146-, CD144-, and CD105-positive cells are largely distributed in the vessel walls and the perivascular region of the Wharton's jelly, whereas CD105 and CD34 are strongly expressed in endothelial cells. CD73 expression has been found throughout the vessels and endothelium, absent in the perivascular region, and highest in the epithelium and sub-epithelial regions of Wharton's jelly matrix. CD90 is exp-ressed in most regions but not in the endothelial lumen lining. A high expression of vimentin, CKs $(1,4,5,6,8,10$, 13,18 and 19), desmin and SMA [88] has been detected in the subamniotic layer and perivascular region. On the contrary, the intervascular layer presents high positivity for vimentin and desmin but the expression level of CKs and SMA is low. Taken together, these findings corroborate the presence of different MSC populations inside hUC.

Overall, compelling evidence indicates Wharton's jelly as the best source of MSCs. Indeed, the findings collected by several studies suggest a wide range of therapeutic applications for these cells. The differentiation potential makes them attractive tools for the replacement of injured cells. The production of cytokines and growth factors as well as the immunomodulatory properties [89] represent the rationale for their employment in the treatment of fibrotic diseases, to support the ex vivo expansion of hematopoietic stem cells from UCB and improve their in vivo engraftment. Furthermore, Ayuzawa et al., [90] have suggested that MSCs from Wharton's jelly may be a useful tool for cancer cytotherapy. Indeed, they reduce MDA 231 metastatic lung tumor growth in SCID mice. This effect is related to the cell homing in on the tumour site, where MSCs probably produce cytotoxic compounds altering the cell cycle of cancer cells. 


\section{COMPARISON BETWEEN MSCS FROM UMBILI- CAL CORD AND BONE MARROW}

To date, due to their application in regenerative medicine, BM-MSCs represent the "gold standard" for the evaluation of stemness properties of MSCs obtained from various sources. In this section, some research works, where the phenotype of UC-MSCs has been directly compared to that of BM-MSCs by means of flow cytometry (FC), RTPCR, or immunocytochemistry (ICC) techniques, have been summarized. Overall, although the two cell population share several cell surface proteins, the differences seem to be mainly related to markers of committed states and molecules with immunomodulatory properties.

Comparing the gene expression profiles of BM-MSCs and subendothelial layer-derived UC-MSCs, Panepucci et al., [17] have shown similarities among the two lineages. Nevertheless, BM-MSCs seem to be more committed to osteogenesis, because they express genes such as biglycan, $T S C 22$, CD44, and vitronectin. On the contrary, genes related to angiogenesis, such as $C X C L 6, I L-8$, IL-1 receptorlike ligand, $M M P 1$, have been expressed exclusively or at higher levels in the UC-MSCs. Using ICC analysis and FC, Suldal'tzeva et al., [91] have compared the phenotypic profile of subendothelial layer-derived UC-MSCs, BM-MSCs, and skin fibroblasts. Their results have shown that UC-MSCs, but not BM-MSCs, express nestin, collagen type 1 and 2, whereas CD106 is only present on BM-MSCs. The Authors have suggested that the phenotypic profile of UC-MSCs is intermediate between those of BM-MSCs and skin fibroblasts, because UC-MSCs expressed markers of both stem cells and differentiated cells. On the other hand, Covas et al. [92] have reported that MSCs from the subendothelial layer present a gene expression profile very similar to that of BMMSCs and related to pericytes. Indeed, although at various degrees, they have found a common expression of genes, such as CD146, NG2, CD271, and CD140B. These findings indicate that the vascular wall contains a MSC compartment composed of fibroblasts, pericytes, and UC-MSCs that may derive from a common stem cell. Furthermore, it has been proposed that fibroblast-specific protein-1 (FSP-1) and CD146 may be used to monitor the differentiation pathways because the percentage expression of these markers are different between the two cell populations: in fibroblasts the expression levels of FSP-1 and CD146 are higher and lower, respectively, than those determined in MSCs.

Although MSCs derived from Wharton's jelly also present a phenotypic profile resembling, at least in part, that of BM-MSCs, some differences exist between the two cell populations. Friedman et al., [45] have reported that CD49b is expressed by UC-MSCs, whereas BM-MSCs lack this marker. The expression levels of HLA-I and CD73 are lower in UC-MSCs than those detected in BM-MSCs. The presence of 11 cell surface markers have been verified by Martin-Rendon et al., [34] in MSC cultures derived from BM, Wharton's jelly, and the perivascular zone of hUC. The three cell populations were phenotypically similar, except for CD106 that was weakly expressed in BM-MSCs and absent in UC-MSCs. Yoo et al., [51] have determined not only cell surface stem cell markers but also cytokines, chemokines, and growth factors that are secreted by BM-MSCs and Wharton's jelly-derived MSCs. In addition to IL-6, IL-8,
MCP-1 that were produced by both cell types, IL-12, IL-15, RANTES and PDGF-AA were secreted only by UC-MSCs, while VEGF was expressed by BM-MSCs, but not by UCMSCs. Furthermore, the Authors have demonstrated that UC-MSCs, like BM-MSCs, were able to suppress mitogeninduced T-cell proliferation, suggesting that they can be used, instead of BM-MSCs, to enhance the engraftment of allogeneic hematopoietic stem cells and to reduce the incidence of graft versus host disease.

This latter observation agrees with the results obtained by $\mathrm{Lu}$ et al., [72], which have compared BM-MSCs with MSCs derived from whole UC. Indeed, they have reported that UCMSCs expressed HLA-I at lower levels than BM-MSCs and produced G-CSF and GM-CSF, cytokines inducing hematopoietic stem cell proliferation, that was not revealed in BMMSCs. Taken together, these findings support the use of UCMSCs for allogeneic cell therapy. Moreover, the same Authors have demonstrated that the CFU-F frequency was higher in UC-MSCs than BM-MSCs. Higher proliferation rates in MSCs cultures derived from Wharton's jelly in comparison with BM-MSC ones were also reported by Chen et al., [79]. As already observed for subendothelial layerderived MSCs [17], Wharton's jelly-derived MSCs seem to possess a higher endothelial differentiation potential than BM-MSCs. Indeed, after endothelial induction, UC-MSCs expressed higher levels of endothelial markers, such as KDR, vWf, and VE-cadherin, than BM-MSCs.

\section{CONCLUSIONS AND PERSPECTIVES}

A great deal of evidence obtained both in vitro and in vivo have demonstrated that $\mathrm{UC}-\mathrm{MSCs}$ isolated from the various parts of the cord are very promising tools for clinical applications. However, MSCs from Wharton's jelly seem to possess greater therapeutic potential than the ones obtained from the other UC zones. Indeed, they possess a wide differentiation potential suggesting their use for tissueengineered constructs [93] and cell therapy [61] to replace injured tissues and cells. They have been successfully used in animal models for increasing angiogenesis in brain ischemia [44], inducing liver regeneration after hepatectomia [3], and replacing neuronal elements in Parkinson's models [42]. Moreover, MSCs from Wharton's jelly, like BMMSCs, are able to support hematopoietic stem cell proliferation [46] and increase the engrafment of these cells in NODSCID mice [45]. Recently, their potential use for cancer cytotherapy has been suggested [90]. All these effects seem to be related to the production of a wide panel of factors. One of the main issues to be addressed is the identification of these factors to fully understand the exact mechanisms responsible for the properties of MSCs. In this context, a detailed report on transcriptome profile of MSCs from Wharton's jelly has been provided by Fong et al., [94] through Affymetrix DNA microarray analysis. The results have shown that the upregulation of genes associated with immune system processes related to antigen processing and presentation, immune system development and activation can be responsible for the immomodulatory properties. On the other hand, the homing in on tumour cells can be due to semaphorin $\mathrm{E}$, promoting cell migration and possessing a high affinity for receptors over-expressed in tumor cells. 
Furthermore, the expression of several tumour suppressor genes may account for the lack of in vivo teratoma induction.

When compared with BM-MSCs, MSCs from Wharton's jelly present several advantages related to easier availability, higher proliferation rates, lower expression of HLA-I coupled to the presence of HLA-G and better immunomodulatory properties. Furthermore, they maintain their multipotent characteristics for longer periods in vitro than BMMSCs [94].

Despite these compelling evidence, the high heterogeneity in extraction, culture and analysis procedures hinder precisely identifying these cells. As a result, different phenotypic profiles are detectable not only among the cells obtained from the various parts of UC, but also inside the same UC regions [95-97]. The available data suggest the UC-MSCs may represent a unique cell family whose components present various degrees of stemness. However, standardized and shared procedures should be useful not only to verify this hypothesis and define the identity of each cell subset, but also to identify the most primitive cell population possessing the highest potentialities for clinical applications.

Finally, since the amount of MSCs isolated from Wharton's jelly (about $4 \times 10^{6} \mathrm{cells} / \mathrm{cm}^{2}$ ) is not sufficient for transplantation therapy [98], the optimization of protocols for the expansion and storage of these cells are needed to assure their efficient use for regenerative medical purposes. Regarding these issues, it has been highlighted that complex media, containing growth supplements, such as insulintransferrin-selenium $G$ and FGF, improve cell proliferation without affecting stemness properties [98]. On the other hand, the pretreatment of MSCs with $10 \mu \mathrm{M} \mathrm{Y}-27632$, a ROCK inhibitor, for $24 \mathrm{~h}$ before freezing has been shown to increase cell survival and maintain stemness and differentiation potential after thawing [99].

Undoubtedly, MSCs from Wharton's jelly represent a great promise for human health. Although their versatility makes them particularly attractive, several questions must be answered and several problems must be solved before their entry in clinical settings. What is the most primitive MSC population inside the cord? By which mechanisms MSCs modulate the immune system and exert other functions not strictly related to cell replacement? What are the most suitable protocols to enhance their in vitro expansion and their storage? In summary, to successfully use MSCs in cellbased therapy, it seems noteworthy to further investigate the mechanisms underlying the functions of these cells and standardize protocols for their isolation, expansion, and characterisation.

$\begin{array}{ll}\begin{array}{ll}\text { ABBREVIATIONS } \\ \text { ACTG2 }\end{array} & \begin{array}{l}\text { Gene (protein-coding), actin, gamma- } \\ \text { enteric smooth muscle }\end{array} \\ = & \begin{array}{l}\text { Gene (protein-coding), actin, alpha 2, } \\ \text { smooth muscle, aorta }\end{array} \\ \text { ACTA2 } & \text { Alkaline phosphatase } \\ \text { AP } & \text { Basic fibroblast growth factor } \\ \mathrm{bFGF} & =\text { Bone marrow }\end{array}$
$\mathrm{CCE}=$ Counterflow centrifugal elutriation
CEA $=$ Carcino-embryonic antigen
CFU-F = Colony-forming-unit fibroblasts
$\mathrm{CK} \quad=$ Cytokeratin
EGF $=$ Epidermal growth factor
Esg1 = Embryonal stem cell-specific gene 1
FBS $=$ Fetal bovine serum
FCS $=$ Fetal calf serum
FC $\quad$ Flow cytometry
FSP-1 = Fibroblast-specific protein-1
G-CSF $=$ Granulocyte colony-stimulating factor
GM-CSF = Granulocyte-macrophage colony- stimulating factor
GFAP $=$ Glial fibrillary acidic protein
$\mathrm{HG} \quad=$ High glucose
HLA $=$ Human leukocyte antigen
HNF4 = Hepatocyte nuclear factor 4
hUC $=$ Human umbilical cord
$\mathrm{KDR}(\mathrm{Flk}-1)=$ Kinase insert domain receptor
ICAM = Intercellular adhesion molecule
ICC = Immunocytochemistry
LIFR $=$ Leukemia inhibitory factor receptor
$\mathrm{LG} \quad=$ Low glucose
MMPs = Matrix metalloproteinases
MSCs = Mesenchymal stromal cells
MYF5 = Myogenic factor 5
NSE $\quad=$ Neuron-specific enolase
Oct $=$ Octamer-binding transcription factor
OPN $=$ Osteopontin
PDGF = Platelet-derived growth factor
PEDF $=$ Pigment epithelium-derived growth factor
REX $=$ Ring-exported protein
$\mathrm{SCF} \quad=$ Stem cell factor
$\mathrm{SHH}=$ Sonic hedgehog homolog
SMA $=\alpha$-smooth muscle actin
SREBP
TERT
TGF
UCB
$\mathrm{UCL}$
VEGF
vWf
$=$ Sterol regulatory element-binding proteins
$=$ Telomerase reverse transcriptase.
$=$ Trasforming growth factor
$=$ Umbilical cord blood
$=$ Umbilical cord lining
$=$ Vascular endothelial growth factor
$=$ Von Willebrand factor 


\section{ACKNOWLEDGEMENT}

None declared.

\section{CONFLICT OF INTEREST}

None declared.

\section{REFERENCES}

[1] McElreavey KD, Irvine AI, Ennis KT, McLean WH. Isolation, culture and characterisation of fibroblast-like cells derived from the Wharton's jelly portion of human umbilical cord. Biochem Soc Trans 1991; 19(1): 29S.

[2] Cheng H, Qiu L, Ma J, et al. Replicative senescence of human bone marrow and umbilical cord derived mesenchymal stem cells and their differentiation to adipocytes and osteoblasts. Molecular Biology Report 29 Dec 2010. Available from: http://www. springerlink.com/content/ q2w5214q2493v675/fulltext.pdf

[3] Campard D, Lysy PA, Najimi M, Sokal EM. Native umbilical cord matrix stem cells express hepatic markers and differentiate into hepatocyte-like cells. Gastroenterology 2008; 134(3): 833-48.

[4] Pereira WC, Khushnooma I, Madkaikar M, Ghosh K. Reproducible methodology for the isolation of mesenchymal stem cells from human umbilical cord and its potential for cardiomyocyte generation. J Tissue Eng Regen Med 2008; 2(7): 394-9.

[5] Weiss ML, Troyer DL. Stem cells in the umbilical cord. Stem Cell Rev 2006; 2(2): 155-62

[6] Huang P, Lin LM, Wu XY, et al. Differentiation of human umbilical cord Wharton's jelly-derived mesenchymal stem cells into germ-like cells in vitro. J Cell Biochem 2010; 109(4): 747-54.

[7] Fu YS, Cheng YC, Lin MY, et al. Conversion of human umbilical cord mesenchymal stem cells in Wharton's jelly to dopaminergic neurons in vitro: potential therapeutic application for Parkinsonism. Stem Cells 2006; 24(1): 115-24.

[8] Weiss ML, Anderson C, Medicetty S, et al. Immune properties of human umbilical cord Wharton's jelly-derived cells. Stem Cells 2008; 26(11): 2865-74.

[9] Lu LL, Song YP, Wei XD, Fang BJ, Zhang YL, Li YF, Comparative characterization of mesenchymal stem cells from human umbilical cord tissue and bone marrow. Zhongguo Shi Yan Xue Ye Xue Za Zhi 2008; 16(1): 140-6.

[10] Can A, Karahuseyinoglu S. Concise review: human umbilical cord stroma with regard to the source of fetus-derived stem cells. Stem Cells 2007; 25(11): 2886-95.

[11] Takechi K, Kuwabara Y, Mizuno M. Ultrastructural and immunohistochemical studies of Wharton's jelly umbilical cord cells. Placenta 1993; 14(2): 235-45.

[12] Salem HK, Thiemermann C. Mesenchymal stromal cells: current understanding and clinical status. Stem Cells 2010; 28(3): 585-96.

[13] Campagnoli C, Roberts IA, Kumar S, Bennett PR, Bellantuono I, Fisk NM. Identification of mesenchymal stem/progenitor cells in human first-trimester fetal blood, liver and bone marrow. Blood 2001; 98(8): 2396-402.

[14] Dominici M, Le Blanc K, Mueller I, et al. Minimal criteria for defining multipotent mesenchymal stromal cells. The International Society for Cellular Therapy position statement. Cytotherapy 2006; 8(4): 315-7.

[15] Romanov YA, Svintsitskaya VA, Smirnov VN. Searching for alternative sources of postnatal human mesenchymal stem cells: candidate MSC-like cells from umbilical cord. Stem Cells 2003; 21(1): 105-10

[16] Covas DT, Siufi JL, Silva AR, Orellana MD. Isolation and culture of umbilical vein mesenchymal stem cells. Braz J Med Biol Res 2003; 36(9): 1179-83.

[17] Panepucci RA, Siufi JL, Silva WA, et al. Comparison of gene expression of umbilical cord vein and bone marrow-derived mesenchymal stem cells. Stem Cells 2004; 22(7): 1263-78.

[18] Kim JW, Kim SY, Park SY, et al. Mesenchymal progenitor cells in the human umbilical cord. Ann Hematol 2004; 83(12): 733-8

[19] Kadivar M, Khatami S, Mortazavi Y, Shokrgozar MA, Taghikhani $\mathrm{M}$, Soleimani M. In vitro cardiomyogenic potential of human umbilical vein-derived mesenchymal stem cells. Biochem Biophys Res Commun 2006; 340(2): 639-47.
Park KS, Jung KH, Kim SH, et al. Functional expression of ion channels in mesenchymal stem cells derived from umbilical cord vein. Stem Cells 2007; 25(8): 2044-52.

[21] Koh SH, Kim KS, Choi MR, et al. Implantation of human umbilical cord-derived mesenchymal stem cells as a neuroprotective therapy for ischemic stroke in rats. Brain Res 2008; 1229: 233-48.

Secco M, Zucconi E, Vieira NM, et al. Multipotent stem cells from umbilical cord: cord is richer than blood. Stem Cells 2008; 26(1): 146-50.

[23] Pruszak J, Ludwig W, Blak A, Alavian K, Isacson O. CD15, CD24, and CD29 define a surface biomarker code for neural lineage differentiation of stem cells. Stem Cells 2009; 27(12): 2928-40.

[24] Gimble JM, Katz AJ, Bunnell BA. Adipose-derived stem cells for regenerative medicine. Circ Res 2007; 11; 100(9): 1249-60.

[25] Baumann M, Krause M, Thames H, Trott K, Zips D. Cancer stem cells and radiotherapy. Int J Radiat Biol 2009; 85(5): 391-402.

[26] Ip JE, Wu Y, Huang J, Zhang L, Pratt RE, Dzau VJ. Mesenchymal stem cells use integrin betal not CXC chemokine receptor 4 for myocardial migration and engraftment. Mol Biol Cell 2007; 18(8): 2873-82.

[27] Linhares-Lacerda L, Ribeiro-Alves M, Nogueira AC, et al. RNA interference-mediated knockdown of CD49e ( $\alpha 5$ integrin chain) in human thymic epithelial cells modulates the expression of multiple genes and decreases thymocyte adhesion. BMC Genomics 2010;11 (Suppl 5): S2.

[28] Avigdor A, Goichberg P, Shivtiel S, et al. CD44 and hyaluronic acid cooperate with SDF-1 in the trafficking of human CD34+ stem/progenitor cells to bone marrow. Blood 2004; 103(8): 2981-9.

[29] Liu Y, Han SS, Wu Y, et al. CD44 expression identifies astrocyterestricted precursor cells. Dev Biol 2004; 276(1): 31-46.

[30] Crosby HA, Lalor PF, Ross E, Newsome PN, Adams DH. Adhesion of human haematopoietic $(\mathrm{CD} 34+)$ stem cells to human liver compartments is integrin and CD44 dependent and modulated by CXCR3 and CXCR4. J Hepatol 2009; 51(4): 734-49.

[31] Wang GK, Hu L, Fuller GN, Zhang W. An interaction between insulin-like growth factor-binding protein 2 (IGFBP2) and integrin alpha5 is essential for IGFBP2-induced cell mobility. J Biol Chem 2006; 281(20): 14085-91.

[32] Ren G, Zhao X, Zhang L, et al. Inflammatory cytokine-induced intercellular adhesion molecule-1 and vascular cell adhesion molecule-1 in mesenchymal stem cells are critical for immunosuppression. J Immunol 2010; 184(5): 2321-8.

[33] Kehler J, Tolkunova E, Koschorz B, et al. Oct4 is required for primordial germ cell survival. EMBO Rep 2004; 5(11): 1078-83.

[34] Martin-Rendon E, Sweeney D, Lu F, Girdlestone J, Navarrete C, Watt SM. 5-Azacytidine-treated human mesenchymal stem/progenitor cells derived from umbilical cord, cord blood and bone marrow do not generate cardiomyocytes in vitro at high frequencies. Vox Sang 2008; 95(2): 137-48.

[35] Sarugaser R, Hanoun L, Keating A, Stanford WL, Davies JE. Human mesenchymal stem cells self-renew and differentiate according to a deterministic hierarchy. PLoS One 2009; 4(8): e6498.

[36] Farias VA, Linares-Fernandez JL, Penalver JL, et al. Human umbilical cord stromal stem cell express CD10 and exert contractile properties. Placenta 2011; 32(1): 86-95.

[37] Sarugaser R, Lickorish D, Baksh D, Hosseini MM, Davies JE. Human umbilical cord perivascular (HUCPV) cells: a source of mesenchymal progenitors. Stem Cells 2005; 23(2): 220-9.

[38] Conrad C, Zeindl-Eberhart E, Moosmann S, Nelson PJ, Bruns CJ, Huss R. Alkaline phosphatase, glutathione-S-transferase-P, and cofilin-1 distinguish multipotent mesenchymal stromal cell lines derived from the bone marrow versus peripheral blood. Stem Cells Dev 2008; 17(1): 23-7.

[39] Freisinger E, Cramer C, Xia X, et al. Characterization of hematopoietic potential of mesenchymal stem cells. J Cell Physiol 2010; 225(3): 888-97.

[40] Wang HS, Hung SC, Peng ST, et al. Mesenchymal stem cells in the Wharton's jelly of the human umbilical cord. Stem Cells 2004; 22(7): 1330-7.

[41] Ma L, Feng XY, Cui BL, et al. Human umbilical cord Wharton's Jelly-derived mesenchymal stem cells differentiation into nervelike cells. Chin Med J 2005; 118(23): 1987-93.

[42] Weiss ML, Medicetty S, Bledsoe AR, et al. Human umbilical cord matrix stem cells: preliminary characterization and effect of 
transplantation in a rodent model of Parkinson's disease. Stem Cells 2006 ;24(3): 781-92.

[43] Conconi MT, Burra P, Di Liddo R, et al. CD105(+) cells from Wharton's jelly show in vitro and in vivo myogenic differentiative potential. Int J Mol Med 2006; 18(6): 1089-96.

[44] Ding DC, Shyu WC, Chiang MF, et al. Enhancement of neuroplasticity through upregulation of beta1-integrin in human umbilical cord-derived stromal cell implanted stroke model. Neurobiol Dis 2007; 27(3): 339-53.

[45] Friedman R, Betancur M, Boissel L, Tuncer H, Cetrulo C, Klingemann H. Umbilical cord mesenchymal stem cells: adjuvants for human cell transplantation. Biol Blood Marrow Transplant 2007; 13(12): 1477-86.

[46] Bakhshi T, Zabriskie RC, Bodie S, et al. Mesenchymal stem cells from the Wharton's jelly of umbilical cord segments provide stromal support for the maintenance of cord blood hematopoietic stem cells during long-term ex vivo culture. Transfusion 2008; 48(12): 2638-44.

[47] Majore I, Moretti P, Hass R, Kasper C. Identification of subpopulations in mesenchymal stem cell-like cultures from human umbilical cord. Cell Commun Signal 2009; 7: 6.

[48] Moodley Y, Atienza D, Manuelpillai U, et al. Human umbilical cord mesenchymal stem cells reduce fibrosis of bleomycin-induced lung injury. Am J Pathol 2009; 175(1): 303-13.

[49] Tsai PC, Fu TW, Chen YM, et al. The therapeutic potential of human umbilical mesenchymal stem cells from Wharton's jelly in the treatment of rat liver fibrosis. Liver Transpl 2009; 15(5): 48495.

[50] Wang SH, Lin SJ, Chen YH, et al. Late outgrowth endothelial cells derived from Wharton jelly in human umbilical cord reduce neointimal formation after vascular injury: involvement of pigment epithelium-derived factor. Arterioscler Thromb Vasc Biol 2009; 29(6): 816-22.

[51] Yoo KH, Jang IK, Lee MW, et al. Comparison of immunomodulatory properties of mesenchymal stem cells derived from adult human tissues. Cell Immunol 2009; 259(2): 150-6.

[52] Kadam SS, Tiwari S, Bhonde RR. Simultaneous isolation of vascular endothelial cells and mesenchymal stem cells from the human umbilical cord. In Vitro Cell Dev Biol Anim 2009; 45(1-2): 23-7.

[53] Angelucci S, Marchisio M, Di Giuseppe F, et al. Proteome analysis of human Wharton's jelly cells during in vitro expansion. Proteome Sci 2010; 8: 18 .

[54] Hartmann I, Hollweck T, Haffner S, et al. Umbilical cord tissuederived mesenchymal stem cells grow best under GMP-compliant culture conditions and maintain their phenotypic and functional properties. J Immunol Methods 2010 15; 363(1): 80-9.

[55] Lavrentieva A, Majore I, Kasper C, Hass R. Effects of hypoxic culture conditions on umbilical cord-derived human mesenchymal stem cells. Cell Commun Signal 2010; 8: 18 .

[56] Tong CK, Vellasamy S, Chong Tan B, et al. Generation of mesenchymal stem cell from human umbilical cord tissue using a combination enzymatic and mechanical disassociation method. Cell Biol Int 2011; 35(3): 221-6.

[57] Fong CY, Chak LL, Biswas A, et al. Human Wharton's Jelly stem cells have unique transcriptome profiles compared to human embryonic stem cells and other mesenchymal stem cells. Stem Cell Rev 2011; 7(1): 1-16.

[58] Oktar PA, Yildirim S, Balci D, Can A. Continual expression throughout the cell cycle and downregulation upon adipogenic differentiation makes nucleostemin a vital human MSC proliferation marker. Stem Cell Rev 2010. Available from: http://www.springerlink.com/content/x4r4751682369327/fulltext.p df

[59] Peng J, Wang Y, Zhang L, et al. Human umbilical cord Wharton's jelly-derived mesenchymal stem cells differentiate into a Schwanncell phenotype and promote neurite outgrowth in vitro. Brain Res Bull 2011; 84(3): 235-43.

[60] Prasanna SJ, Gopalakrishnan D, Shankar SR, Vasandan AB. Proinflammatory cytokines, IFNgamma and TNFalpha, influence immune properties of human bone marrow and Wharton jelly mesenchymal stem cells differentially. PLoS One 2010; 5(2): e9016.

[61] Kadam SS, Bhonde RR. Islet neogenesis from the constitutively nestin expressing human umbilical cord matrix derived mesenchymal stem cells. Islets 2010; 2(2): 112-20.
[62] Struys T, Moreels M, Martens W, Donders R, Wolfs E, Lambrichts I. Ultrastructural and immunocytochemical analysis of multilineage differentiated human dental pulp- and umbilical cord-derived mesenchymal stem cells. Cells Tissues Organs 2011; 193(6): 36678.

[63] Arufe MC, De la Fuente A, Mateos J, Fuentes I, De Toro FJ, Blanco FJ. Analysis of the chondrogenic potential and secretome of mesenchymal stem cells derived from human umbilical cord stroma. Stem Cells Dev. 29 Dec 2010. Available from: http://www.liebertonline.com/doi/pdf/10.1089/scd.2010.0315

[64] Zarkhin V, Talisetti A, Li L, et al. Expression of soluble HLA-G identifies favorable outcomes in liver transplant recipients. Transplantation 2010; 90(9): 1000-5.

[65] Gonzalez R, Griparic L, Umana M, et al. An efficient approach to isolation and characterization of pre- and postnatal umbilical cord lining stem cells for clinical applications. Cell Transplant 2010; 19(11): 1439-49

[66] Reza HM, Ng BY, Phan TT, Tan DT, Beuerman RW, Ang LP. Characterization of a novel umbilical cord lining cell with CD227 positivity and unique pattern of P63 expression and function. Stem Cell Rev 2010. Available from: http://www.springerlink. com/content/xq2n2224rv82t113/fulltext.pdf

[67] Seta N, Kuwana M. Derivation of multipotent progenitors from human circulating CD14+ monocytes. Exp Hematol 2010; 38(7): 557-63.

[68] McAuley JL, Linden SK, Png CW, et al. MUC1 cell surface mucin is a critical element of the mucosal barrier to infection. $\mathrm{J}$ Clin Invest 2007; 117(8): 2313-24.

[69] Chometon G, Zhang ZG, Rubinstein E, Boucheix C, Mauch C, Aumailley M. Dissociation of the complex between CD151 and laminin-binding integrins permits migration of epithelial cells. Exp Cell Res 2006; 312(7): 983-95.

[70] Hackett TL, Shaheen F, Johnson A, et al. Characterization of side population cells from human airway epithelium. Stem Cells 2008; 26(10): 2576-85

[71] Tsagias N, Koliakos I, Karagiannis V, Eleftheriadou M, Koliakos GG. Isolation of mesenchymal stem cells using the total length of umbilical cord for transplantation purposes. Transfus Med 2011. doi: 10.1111/j.1365-3148.2011.01076.x.

[72] Lu LL, Liu YJ, Yang SG, et al. Isolation and characterization of human umbilical cord mesenchymal stem cells with hematopoiesissupportive function and other potentials. Haematologica 2006; 91(8): 1017-26.

[73] Yan Y, Xu W, Qian H, et al. Mesenchymal stem cells from human umbilical cords ameliorate mouse hepatic injury in vivo. Liver Int 2009; 29(3): 356-65.

[74] Yoon JH, Roh EY, Shin S, et al. Introducing pulsed low-intensity ultrasound to culturing human umbilical cord-derived mesenchymal stem cells. Biotechnol Lett 2009; 31(3): 329-35.

[75] Qiao $\mathrm{C}, \mathrm{Xu} \mathrm{W}, \mathrm{Zhu} \mathrm{W}$, et al. Human mesenchymal stem cells isolated from the umbilical cord. Cell Biol Int 2008; 32(1): 8-15.

[76] Jo CH, Kim OS, Park EY, et al. Fetal mesenchymal stem cells derived from human umbilical cord sustain primitive characteristics during extensive expansion. Cell Tissue Res 2008; 334(3): 423-33.

[77] La Rocca G, Anzalone R, Corrao S, et al. Isolation and characterization of Oct-4+/HLA-G+ mesenchymal stem cells from human umbilical cord matrix: differentiation potential and detection of new markers. Histochem Cell Biol 2009; 131(2): 26782.

[78] La Rocca G, Anzalone R, Farina F. The expression of CD68 in human umbilical cord mesenchymal stem cells: new evidences of presence in non-myeloid cell types. Scand J Immunol 2009; 70(2): 161-2.

[79] Chen MY, Lie PC, Li ZL, Wei X. Endothelial differentiation of Wharton's jelly-derived mesenchymal stem cells in comparison with bone marrow-derived mesenchymal stem cells. Exp Hematol 2009; 37(5): 629-40.

[80] Secco M, Moreira YB, Zucconi E, et al. Gene expression profile of mesenchymal stem cells from paired umbilical cord units: cord is different from blood. Stem Cell Rev 2009; 5(4): 387-401.

[81] Schugar RC, Chirieleison SM, Wescoe KE, et al. High harvest yield, high expansion, and phenotype stability of CD146 mesenchymal stromal cells from whole primitive human umbilical cord tissue. J Biomed Biotechnol 2009; 789526.

[82] Yaghoobi MM, Mowla SJ, Tiraihi T. Nucleostemin, a coordinator of self-renewal, is expressed in rat marrow stromal cells and turns 
off after induction of neural differentiation. Neurosci Lett 2005; 390(2): 81-6.

[83] Yadirgi G, Leinster V, Acquati S, Bhagat H, Shakhova O, Marino S. Conditional activation of Bmil expression regulates self renewal, apoptosis and differentiation of neural stem/progenitor cells in vitro and in vivo. Stem cells. 2011. Available from: http://onlinelibrary.wiley.com/doi/10.1002/stem.614/abstract

[84] Fuks A, Banjo C, Shuster J, Freedman SO, Gold P. Carcinoembryonic antigen (CEA): molecular biology and clinical significance. Biochim Biophys Acta 1975; 417(2): 123-52.

[85] Yasuda K, Yashiro M, Sawada T, Ohira M, Hirakawa K. ERas oncogene expression and epigenetic regulation by histone acetylation in human cancer cells. Anticancer Res 2007; 27(6B): 4071-5.

[86] Afouda BA, Hoppler S. Different requirements for GATA factors in cardiogenesis are mediated by non-canonical Wnt signaling. Dev Dyn 2011; 240(3): 649-62.

[87] Song D, Liu X, Liu R, Yang L, Zuo J, Liu W. Connexin 43 hemichannel regulates $\mathrm{H} 9 \mathrm{c} 2$ cell proliferation by modulating intracellular ATP and $\left[\mathrm{Ca}^{2+}\right]$. Acta Biochim Biophys Sin (Shanghai) 2010; 42(7): 472-82.

[88] Karahuseyinoglu S, Cinar O, Kilic E, et al. Biology of stem cells in human umbilical cord stroma: in situ and in vitro surveys. Stem Cells 2007; 25(2): 319-31

[89] Tipnis S, Viswanathan C, Majumdar AS. Immunosuppressive properties of human umbilical cord-derived mesenchymal stem cells: role of B7-H1 and IDO. Immunol Cell Biol 2010; 88(8): 795806.

[90] Ayuzawa R, Doi C, Rachakatla RS, et al. Naïve human umbilical cord matrix derived stem cells significantly attenuate growth of human breast cancer cells in vitro and in vivo. Cancer Lett 2009; 280(1): 31-7.

[91] Suzdal'tseva YG, Burunova VV, Petrakova NV, Vakhrushev IV, Yarygin KN, Yarygin VN. Comparative analysis of cytophenotypes of cells of mesenchymal lineage isolated from human tissues. Bull Exp Biol Med 2007; 143(1): 147-54.
[92] Covas DT, Panepucci RA, Fontes AM, et al. Multipotent mesenchymal stromal cells obtained from diverse human tissues share functional properties and gene-expression profile with CD146+ perivascular cells and fibroblasts. Exp Hematol 2008; 36(5): 642-54.

[93] Gauthaman K, Venugopal JR, Yee FC, Biswas A, Ramakrishna S, Bongso A. Osteogenic differentiation of human Wharton's jelly stem cells on nanofibrous substrates in vitro. Tissue Eng Part A 2011; 17(1-2): 71-81.

[94] Fong CY, Chak LL, Biswas A, et al. Human Wharton's jelly stem cells have unique transcriptome profiles compared to human embryonic stem cells and other mesenchymal stem cells. Stem Cell Rev 2011; 7(1): 1-16.

[95] Meyer T, Pfeifroth A, Hocht B. Isolation and characterization of mesenchymal stem cells in Wharton's jelly of the human umbilical cord: potent cells for cell-based therapies in paediatric surgery? Eur Surg 2008 40(5): 239-244.

[96] Weiss ML, Medicetty S, Bledsoe AR, et al. Human umbilical cord matrix stem cells: preliminary characterization and effect of transplantation in a rodent model of Parkinson's disease. Stem Cells 2006; 24(3): 781-92.

[97] Fu YS, Cheng YC, Lin MY, et al. Conversion of human umbilical cord mesenchymal stem cells in Wharton's jelly to dopaminergic neurons in vitro: potential therapeutic application for Parkinsonism. Stem Cells 2006; 24(1):115-24.

[98] Fong CY, Subramanian A, Biswas A, et al. Derivation efficiency, cell proliferation, freeze-thaw survival, stem-cell properties and differentiation of human Wharton's jelly stem cells. Reprod Biomed Online 2010; 21(3): 391-401.

[99] Gauthaman K, Fong CY, Subramanian A, Biswas A, Bongso A. ROCK inhibitor Y-27632 increases thaw-survival rates and preserves stemness and differentiation potential of human Wharton's jelly stem cells after cryopreservation. Stem Cell Rev 2010; 6(4): 665-76.

Received: March 14, 2011

Revised: May 20, 2011

Accepted: June 24, 2011

(C) Conconi et al.; Licensee Bentham Open .

This is an open access article licensed under the terms of the Creative Commons Attribution Non-Commercial License (http://creativecommons.org/ licenses/by-nc/3.0/), which permits unrestricted, non-commercial use, distribution and reproduction in any medium, provided the work is properly cited. 